\title{
I. Researches on melting-point
}

\section{Edmund J. Mills D.Sc. F.R.S.}

To cite this article: Edmund J. Mills D.Sc. F.R.S. (1882) I. Researches on melting-point, Philosophical Magazine Series 5, 14:85, 1-29, DOI: 10.1080/14786448208628413

To link to this article: http://dx.doi.org/10.1080/14786448208628413

册 Published online: 28 Apr 2009.

Submit your article to this journal $2 \pi$

Џ Article views: 2

Q View related articles $₫$ 


\section{LONDON, EDINBURGH, AND DUBLIN}

\section{PHILOSOPHICAL MAGAZINE}

\section{AND \\ JOURNAL OF SCIENCE.}

[FIFTH SERIES.]

JUL Y 1882.

I. Researches on Melting-point. By Edmund J. MiLls, D.Se., F.R.S., "Young" Professor of Technical Chemistry in Anderson's College Glasgow*.

TF we desire to ascertain the purity of a chemical substance 1 -in other words, to establish its species-two lines of investigation are open to us. We may (1) by analytical means determine the composition, or (2) measure by physical methods some natural property of the body. Both modes of research require that what is determined-whether composition or natural property-shall be constant over a fair range of genetic condition. Both modes also involve a considerable amount of inference; but, of the two, far less is demanded by the methods of physical seience, which are, as a rule, distinguished by their greater certainty because of their experimental directness. To the property of melting, these characteristics are preeminently applicable.

The accurate ascertainment of melting-point, in terms of the air-thermometer, supplies us with physical constants of considerable importance. While the readings of the mercurial thermometer are subject to grave correction-its zero, in particular, being never stationary,-it is most unlikely that the melting-point of a substance will vary in any ordinary interval of time, under any common change of pressure, or with transition to a distant latitude. Actuated chiefly by these considerations, I undertook the researches of which an account is comprised in the following sections.

* Communicated by the Author.

Phil. Jlag. S. 5. Vol. 14. No. 85. July 1882. 


\section{A. Benzol Derivatives.}

1. Dinitrobenzol.-The benzol from which specimens A and $\mathrm{C}$ were prepared had been purified by myself, first by fractional distillation, then by fractional distillation after treatment with bromine, and, lastly, by freezing and pressure. The preparation of the dinitro-compound was effected with the aid of hydric sulphate. The crude product was washed with water, alkaline water, and water successively, and then submitted to a process of purification repeatedly adopted in these experiments.

[The process in question consists in crystallization from distinct successive solvents, followed each time by pressure. It is well known that small quantities of impurity are prone to cling to substances with much tenacity; but the observation has most frequently been made in connexion with some single solvent. One can readily conceive that the tenacity with which a given trace of a foreign body is held may, under such circumstances, be in effect constant. If, however, we now transfer the mixture to a new solvent, then, we may fairly presume, the trace will be in a condition of altered adhesiveness, and may be much more readily separable. It is of course not easy to decide whether this result is always attained, or whether the later solvent makes any impression at all; but it will probably be granted that the method of multiple successive solvents is in general expedient to adopt.

After each crystallization the crystals were in all cases submitted to powerful pressure between folds of carefully cleansed linen or, occasionally, of silk tissue. The surface-tension of the dissolved impurities appears to be for the most part considerable; and this, aided by mechanical compression, greatly economizes the time required in preparing a pure substance.

The pressed crystals were next reduced to a very fine powder, and dried for eleven days over oil of vitriol in the dark. Care was taken never to make determinations with substances previously melted; for it not unfrequently happens that a second melting takes place at an appreciably different temperature.]

Specimens $A$ and $C$ were crystallized twice from naphtha, and thrice \&c. $\left(A_{3} \& c ., C_{3}\right.$ \&c. $)$ from purified alcohol. Specimen $B$ was given me by Mr. C. E. Groves, who had prepared it from thrice frozen and pressed benzol. It was crystallized once from water, once from naphtha, once \&c. $\left(B_{1} \& c.\right)$ from pure alcohol. The results are contained in Table $\mathrm{I}$.

Dinitrobenzol melts with some sharpness after a decided pasty stage. It strongly resists pulverization-a character more especially observable in specimen $B$. 
Dr. E. J. Mills's Researches on Melting-point.

TABLE I.

\begin{tabular}{|c|c|c|c|c|c|c|c|}
\hline & $\mathbf{A}_{3}$ & $\mathbf{A}_{1}$. & $\mathbf{B}_{1}$ & $\mathbf{B}_{2}$. & $\mathbf{B}_{2^{\prime}}$ & $\mathrm{C}_{3}$. & $\mathrm{C}_{4}$. \\
\hline & $\begin{array}{r}89.86 \\
.75 \\
.75 \\
.78 \\
.73 \\
.75 \\
.81 \\
.78 \\
.81 \\
.67 \\
.75 \\
.59 \\
.81 \\
.83\end{array}$ & $\begin{array}{r}89.71 \\
.71 \\
.74 \\
.68 \\
.84 \\
.76 \\
.82 \\
.79 \\
.84 \\
.84 \\
.79 \\
.82 \\
.82 \\
.71\end{array}$ & $\begin{array}{r}89.79 \\
.82 \\
\cdot 71 \\
\cdot 71 \\
.66 \\
\cdot 68 \\
\cdot 79 \\
66 \\
\cdot 71 \\
.68 \\
\cdot 79 \\
.76 \\
.66 \\
\cdot 74\end{array}$ & $\begin{array}{r}89.75 \\
78 \\
.70 \\
70 \\
70 \\
70 \\
.67 \\
.80 \\
78 \\
70 \\
70 \\
.83 \\
72 \\
72\end{array}$ & $\begin{array}{r}89.64 \\
.71 \\
.66 \\
.64 \\
.66 \\
.74 \\
.71 \\
.69 \\
.71 \\
.74 \\
.71 \\
.62 \\
.64\end{array}$ & $\begin{array}{r}89.73 \\
.62 \\
.73 \\
.76 \\
.73 \\
.70 \\
.76 \\
.73 \\
.65 \\
.78 \\
.76 \\
.73 \\
.68 \\
.65\end{array}$ & $\begin{array}{r}89.67 \\
.59 \\
.62 \\
.67 \\
.64 \\
.73 \\
.64 \\
.62 \\
.75 \\
.70 \\
.62 \\
.78 \\
.70 \\
.59\end{array}$ \\
\hline $\begin{array}{l}\text { Mean ................... } \\
\text { Probable error ... } \\
\text { Thermometer ... }\end{array}$ & $\mid \begin{array}{c}89 \cdot 76 \\
.012 \\
2\end{array}$ & $\begin{array}{c}89 \cdot 78 \\
\cdot 010 \\
2\end{array}$ & $\begin{array}{c}89 \cdot 73 \\
\cdot 010 \\
2\end{array}$ & $\left|\begin{array}{c}89 \cdot 73 \\
.008 \\
2\end{array}\right|$ & $\left|\begin{array}{c}89 \cdot 68 \\
\cdot 007 \\
3\end{array}\right|$ & $\mid \begin{array}{c}89 \cdot 71 \\
\cdot 008 \\
\mathbf{2}\end{array}$ & $\begin{array}{c}89 \cdot 67 \\
.010 \\
2\end{array}$ \\
\hline
\end{tabular}

2. Dichlorobenzol.-For this specimen I was indebted to Dr. Hugo Müller, who prepared it by his well-known process of chlorination, which consists in treating hydrogenated bodies with chlorine in presence of iodine. It was crystallized twice from naphtha, and four times \&c. $\left(A_{4} \& c.\right)$ from alcohol. Dichlorobenzol melts very suddenly.

TABLE II.

\begin{tabular}{|c|c|c|c|c|c|c|c|}
\hline & $A_{1}$ & $A_{5}$. & $\Delta_{6}$. & $\Delta_{i} \cdot$ & $A_{8^{*}}$ & $A_{0}$. & $A_{\gamma}$. \\
\hline & $\begin{array}{r}52 \cdot 61 \\
.66 \\
.74 \\
.71 \\
.74 \\
.79 \\
.74 \\
.71 \\
.76 \\
.71 \\
.69 \\
.76 \\
.74 \\
.79\end{array}$ & $\begin{array}{r}0.72 \\
.72 \\
.70 \\
.67 \\
75 \\
.72 \\
.75 \\
.72 \\
.72 \\
.75 \\
77 \\
.75 \\
.72 \\
.75\end{array}$ & $\begin{array}{r}52.66 \\
71 \\
71 \\
.74 \\
79 \\
74 \\
.76 \\
.79 \\
71 \\
.71 \\
.68 \\
.74 \\
.74 \\
.74\end{array}$ & $\begin{array}{r}5.74 \\
.72 \\
.69 \\
.69 \\
.72 \\
.69 \\
.69 \\
.72 \\
.66 \\
.69 \\
.69 \\
.72 \\
.69 \\
.66\end{array}$ & $\begin{array}{r}52.74 \\
.72 \\
.69 \\
.74 \\
.74 \\
.72 \\
.69 \\
.74 \\
.76 \\
.69 \\
.76 \\
.72 \\
74 \\
.76\end{array}$ & $\begin{array}{r}52.74 \\
.76 \\
.72 \\
.66 \\
.72 \\
.72 \\
.64 \\
.76 \\
.76 \\
.76 \\
.76 \\
.74 \\
.72 \\
.74\end{array}$ & $\begin{array}{r}52.83 \\
.75 \\
.75 \\
.75 \\
.78 \\
.73 \\
.73 \\
.70 \\
.75 \\
.73 \\
.73 \\
.67 \\
.75 \\
.73\end{array}$ \\
\hline $\begin{array}{l}\text { Meaul .................... } \\
\text { Probable error } \ldots \\
\text { Thermometer } \ldots\end{array}$ & $\begin{array}{c}5272 \\
.008 \\
3\end{array}$ & $\begin{array}{c}52 \cdot 73 \\
\cdot 004 \\
3\end{array}$ & $\left|\begin{array}{c}52 \cdot 73 \\
\cdot 006 \\
3\end{array}\right|$ & $\begin{array}{c}5270 \\
\cdot 004 \\
3\end{array}$ & $\begin{array}{c}52 \cdot 73 \\
\cdot 004 \\
3\end{array}$ & $\begin{array}{c}52.73 \\
.006 \\
3\end{array}$ & $\begin{array}{c}52 \cdot 74 \\
\cdot 006 \\
2\end{array}$ \\
\hline
\end{tabular}

3. Dibromobenzol.-A was a sample prepared by heating B 2 
benzol (permanently reddened by bromine) for a short time nearly to boiling, washing and rectifying the product. The benzol thus purified was used in preparing benzol by Couper's process*; and from this product, on distillation, a residue of dibromobenzol was obtained. This was crystallized once from spirit, twice from naphtha, and thrice from spirit; at the last crystallization the substance was only partly dissolved; and the crystals obtained from the solution were alone examined. $C$ was prepared from the monobromobenzol above referred to. The product of Couper's process always contains a little dibromobenzol, which cannot be removed in the ordinary way. This was allowed to remain. Traces of another solid impurity were precipitated by exposure to sunlight for some weeks in presence of solid potassic hydrate, followed by filtration and distillation. Finally the purified monobromobenzol was mixed with bromine in the proportion $\mathrm{C}_{6} \mathrm{H}_{5} \mathrm{Br}: \mathrm{Br}_{2}$, and left for some weeks in the laboratory, during which it was once heated in the water-bath. The product was washed with aqueous caustic soda, some unaltered monobromobenzol removed by partial distillation with water, and the remainder crystallized once from alcohol, once from naphtha, and once from alcohol in presence of charcoal $\left(\mathrm{C}_{1}\right)$ : successive fractions $\left(\mathrm{C}_{2} \& \mathrm{c}\right.$. $)$ from alcohol were then taken. $\mathrm{C}_{6 \alpha}$ was obtained from a hot liquid which had deposited about half its contents, which I have named $\mathrm{C}_{6 \beta}$.

Dibromobenzol melts nearly as sharply as dichlorobenzol. It is hardly possible to trace a pasty stage.

TABLE III.

\begin{tabular}{|c|c|c|c|c|c|c|c|c|c|}
\hline & A. & A. & $\mathrm{C}_{1}$ & $\mathbf{C}_{2}$ & $\mathrm{C}_{3}$ & $\mathrm{C}_{4}$. & $\mathrm{C}_{5}$. & $\mathrm{C}_{6 \alpha}$. & $\mathrm{C}_{6 \beta}$ \\
\hline & $\begin{array}{l}87.08 \\
87.03 \\
86.87 \\
86.97 \\
87.00 \\
86.97 \\
86.95 \\
87.03 \\
87.03 \\
87.08 \\
87.00 \\
87.03 \\
86.97 \\
87.03\end{array}$ & $\begin{array}{l}87.05 \\
87.07 \\
87.03 \\
87.05 \\
87.01 \\
86.96 \\
87.01 \\
87.01 \\
87.05 \\
87.10 \\
87.01 \\
87.03 \\
87.12 \\
87.09\end{array}$ & $\begin{array}{l}87 \cdot 10 \\
86 \cdot 99 \\
87 \cdot 12 \\
86 \cdot 99 \\
87 \cdot 10 \\
87 \cdot 07 \\
86 \cdot 97 \\
87 \cdot 12 \\
86 \cdot 99 \\
87 \cdot 02 \\
86 \cdot 99 \\
87 \cdot 12\end{array}$ & $\begin{array}{l}86.97 \\
87 \cdot 08 \\
86 \cdot 97 \\
87 \cdot 16 \\
87 \cdot 13 \\
86 \cdot 99 \\
87.08 \\
87 \cdot 13 \\
87.05 \\
87.05 \\
87 \cdot 10 \\
87 \cdot 08\end{array}$ & $\begin{array}{l}87.06 \\
87.01 \\
87.03 \\
87.03 \\
87.11 \\
87.01 \\
87.01 \\
86.98 \\
87.11 \\
87.03 \\
87.01 \\
87.03\end{array}$ & $\begin{array}{l}87 \cdot 10 \\
87 \cdot 05 \\
87 \cdot 10 \\
87 \cdot 10 \\
87 \cdot 05 \\
87 \cdot 07 \\
87 \cdot 04 \\
87 \cdot 06 \\
87 \cdot 15 \\
87 \cdot 07 \\
87 \cdot 13 \\
87 \cdot 04\end{array}$ & $\begin{array}{l}87.04 \\
87 \cdot 01 \\
87 \cdot 01 \\
87.01 \\
87.01 \\
87 \cdot 01 \\
86 \cdot 96 \\
87 \cdot 01 \\
86.99 \\
87.04 \\
86.99 \\
86.99\end{array}$ & $\begin{array}{l}87.06 \\
87.06 \\
87.03 \\
86.98 \\
87.09 \\
87.06 \\
87.06 \\
87.06 \\
87.06 \\
87.11 \\
87.03 \\
87.10\end{array}$ & $\begin{array}{l}87.10 \\
87.05 \\
86.94 \\
87.07 \\
87.07 \\
87.07 \\
87.05 \\
87.05 \\
87.02 \\
87.02 \\
87.02 \\
87.02\end{array}$ \\
\hline $\begin{array}{l}\text { Mean ............ } \\
\text { Probable error. } \\
\text { Thermometer.. }\end{array}$ & $\mid \begin{array}{c}87 \cdot 00 \\
.010 \\
2\end{array}$ & $\begin{array}{c}87.04 \\
.007 \\
4\end{array}$ & $\begin{array}{c}87 \cdot 05 \\
\cdot 011 \\
2\end{array}$ & $\begin{array}{c}87 \cdot 06 \\
\cdot 012 \\
2\end{array}$ & $\begin{array}{c}87.04 \\
.007 \\
2\end{array}$ & $\begin{array}{c}87.08 \\
\cdot 007 \\
2\end{array}$ & $\begin{array}{c}87 \cdot 01 \\
\quad 004 \\
2\end{array}$ & $\mid \begin{array}{c}87 \cdot(16 \\
\cdot 006 \\
2\end{array}$ & $\left|\begin{array}{c}87 \cdot 04 \\
\cdot 008 \\
2\end{array}\right|$ \\
\hline
\end{tabular}

* Ann. Chim. Phys. [3] lii. p. 309. 
4. Dinitrobromobenzol.-Benzol purified by bromine distillation, and freezing, was brominated by the Couper process, and freed from dibromobenzol by heating to the boiling-point with a mixture of Nordhausen and common oil of vitriol; this treatment was followed by washing and distillation.

Sample A was prepared from the above bromobenzol by Kekulé's method*. The crude product amounted to 148 per cent., theory requiring 157 per cent. : it contained a small quantity of an oily body. This was crystallized twice from naphtha and five times \&c. ( $A_{5} \&$ c.) from alcohol.

The crystals of dinitrobromobenzol are, as observed by Kekulé, remarkably large and well defined. They powder harshly, like rosin. The concentrated alcoholic solution emits sound as it crystallizes.

Dinitrobromobenzol melts with considerable sharpness.

TABLE IV.

\begin{tabular}{|c|c|c|c|c|c|c|c|}
\hline & $\mathbf{A}_{5}$. & $\Delta_{6}$. & $A_{7}$. & $\mathbf{A}_{\mathbf{3}}$. & $A_{g}$. & $A_{10^{\circ}}$ & $A_{10}$ \\
\hline & $\begin{array}{r}70.53 \\
\cdot 53 \\
\cdot 50 \\
.53 \\
.48 \\
.53 \\
.61 \\
.58 \\
.66 \\
\cdot 53 \\
.64 \\
\cdot 48 \\
\cdot 50 \\
\cdot 56\end{array}$ & $\begin{array}{r}70.54 \\
.51 \\
.65 \\
.49 \\
.51 \\
.57 \\
.51 \\
.65 \\
.59 \\
.57 \\
.54 \\
.54 \\
.67 \\
.62\end{array}$ & $\begin{array}{r}70.56 \\
.64 \\
.61 \\
.64 \\
.56 \\
.67 \\
.59 \\
.59 \\
.48 \\
.67 \\
.69 \\
.67 \\
.64 \\
-67\end{array}$ & $\begin{array}{r}70 \cdot 68 \\
-55 \\
-55 \\
-55 \\
.57 \\
.68 \\
-57 \\
.68 \\
.57 \\
.68 \\
.63 \\
.65 \\
.63 \\
.63\end{array}$ & $\begin{array}{r}70.67 \\
.54 \\
.64 \\
.67 \\
.54 \\
.70 \\
.56 \\
.64 \\
.59 \\
.59 \\
.67 \\
.62 \\
.67 \\
.67\end{array}$ & $\begin{array}{r}70.68 \\
.71 \\
.55 \\
.71 \\
.55 \\
.60 \\
.60 \\
.63 \\
.68 \\
.60 \\
.57 \\
.68 \\
.57 \\
.57\end{array}$ & $\begin{array}{r}70.56 \\
.59 \\
.53 \\
.53 \\
.56 \\
.66 \\
.66 \\
.56 \\
.46 \\
.69 \\
.71\end{array}$ \\
\hline $\begin{array}{l}\text { Mean ................ } \\
\text { Probable error .... } \\
\text { Thermometer } \quad \ldots .\end{array}$ & $\begin{array}{c}70 \cdot 55 \\
.010 \\
2\end{array}$ & $\begin{array}{l}70 \cdot 57 \\
010 \\
2\end{array}$ & $\begin{array}{c}70 \cdot 62 \\
\cdot 010 \\
2\end{array}$ & $\begin{array}{c}70 \cdot 61 \\
\cdot 009 \\
2\end{array}$ & $\begin{array}{c}70 \cdot 62 \\
\cdot 009 \\
2\end{array}$ & $\left|\begin{array}{c}70 \cdot 62 \\
010 \\
2\end{array}\right|$ & $\begin{array}{l}70.59 \\
.015 \\
\mathbf{3}\end{array}$ \\
\hline
\end{tabular}

5. Nitrodibromobenzol.-Sample A, from (D) dibromobenzol (q. v.) which had been crystallized once from alcohol, once from naphtha, and once from alcohol. $25 \mathrm{grm}$. of substance were gently heated with 250 cub. cent. of "fuming nitric acid," and allowed to cool during a rather longer period. The product, purified by means of water and ammonia, contained a little oily impurity, and weighed $28.5 \mathrm{grm}$. (=114 per cent., theory requiring $119 \cdot 1$ per cent.): it was crystallized twice from naphtha, and thrice \&c. $\left(A_{3} \& c.\right)$ from alcohol.

* Ann. Chem. Pharm. cxxxvii. p. 167. 
$B$ was prepared from another portion of (D) dibromobenzol. $25 \mathrm{grm}$. were gently heated for two hours with $250 \mathrm{cub}$. cent. nitrate as before, and allowed to cool during twenty-one hours. The pressed product, which had at first oontained an oily body, weighed $17 \mathrm{grm} .(=68$ per cent.): it was crystallized twice from naphtha, and thrice \&c. $\left(B_{3} \& c\right.$.) from alcohol.

The melting-point of nitrodibromobenzol is satisfactorily sharp.

TABLe V.

\begin{tabular}{|c|c|c|c|c|c|c|c|}
\hline & $A_{3}$ & $A_{4}$. & $A_{5}$. & $\mathbf{B}_{3}$ & $\mathbf{B}_{4}$ & $\mathrm{~B}_{4}$ & $\mathbf{B}_{5}$ \\
\hline & $\begin{array}{r}83.49 \\
.53 \\
\cdot 47 \\
\cdot 55 \\
\cdot 47 \\
\cdot 55 \\
\cdot 53 \\
.53 \\
.47 \\
.49 \\
.53 \\
.55\end{array}$ & $\begin{array}{r}83.43 \\
.48 \\
.46 \\
.54 \\
.46 \\
.43 \\
.48 \\
.54 \\
.54 \\
.48 \\
.51 \\
.51\end{array}$ & $\begin{array}{r}8 \stackrel{8}{3} \cdot 46 \\
\cdot 46 \\
\cdot 51 \\
.43 \\
.49 \\
.43 \\
.51 \\
.49 \\
.49 \\
.46 \\
.49 \\
.49\end{array}$ & $\begin{array}{r}83.46 \\
\cdot 49 \\
\cdot 46 \\
\cdot 43 \\
\cdot 46 \\
\cdot 44 \\
\cdot 39 \\
\cdot 49 \\
\cdot 46 \\
.52 \\
\cdot 44 \\
\cdot 46\end{array}$ & $\begin{array}{r}83.49 \\
.49 \\
.44 \\
.54 \\
.49 \\
.46 \\
.57 \\
.52 \\
.52 \\
.52 \\
.41 \\
.49\end{array}$ & $\begin{array}{r}83.50 \\
.52 \\
.50 \\
\cdot 45 \\
.52 \\
.48 \\
.52 \\
.50 \\
.50 \\
.60 \\
.50 \\
.52\end{array}$ & $\begin{array}{r}83.32 \\
.49 \\
.44 \\
.47 \\
.49 \\
.55 \\
.57 \\
.49 \\
.41 \\
.52 \\
.52 \\
.49\end{array}$ \\
\hline $\begin{array}{l}\text { Mean ................ } \\
\text { Probable error ... } \\
\text { Thermometer } \quad . .\end{array}$ & $\begin{array}{c}83 \cdot 51 \\
\cdot 006 \\
2\end{array} \mid$ & $\left|\begin{array}{c}83 \cdot 49 \\
\cdot 007 \\
2\end{array}\right|$ & $\left|\begin{array}{c}83.48 \\
.005 \\
2\end{array}\right|$ & $\begin{array}{c}83 \cdot 46 \\
.006 \\
2\end{array}$ & $\begin{array}{c}83 \cdot 49 \\
.008 \\
2\end{array}$ & $\begin{array}{l}83 \cdot 51 \\
\cdot 006 \\
3\end{array}$ & $\begin{array}{l}83 \cdot 50 \\
008 \\
2\end{array}$ \\
\hline
\end{tabular}

B. Aniline Derivatives.

1. Monochloraniline.-Sample A was prepared from chlorinated acetanilide*, free from toluol. It was purified by solution in aqueous hydric chloride, evaporating thrice to dryness after filtration, precipitating with ammonia, and distilling in a current of steam. The product was crystallized twice from naphtha, and thrice \&c. $\left(A_{3} \& c.\right)$ from alcohol.

B was prepared more directly from aniline by the following method:-Half a pound of aniline, puritied by cohobation for several hours with one sixteenth of its weight of mercuric chloride, was mixed with a pound of glacial acetate, and chlorine led slowly over its surface. Considerable heat was evolved. When this sign of action ceased to be manifested the mixture was allowed to cool, and the now solid product heated with water and caustic soda : the oily layer thus formed was withdrawn, and cohobated for a few hours with alcoholic potash. Water was next added to this solution and its residue; and the

* For the details of the methods of obtaining aniline derivatives from acetanilide see Proc. Roy. Soc. x. p. 589, and Phil. Mag. 1875, xlix. p. 21. 
united amines thereby precipitated were separated by appropriate treatment with aqueous hydric chloride*. B was crystallized twice from naphtha, and thrice \&c. $\left(B_{3} \& c.\right)$ from alcohol.

The chlorination of acetanilide yields but little dichloraniline; the chlorination of the acetate still less.

Monochloraniline produces great cold when dissolved in alcohol. On the application of heat to its powder, it melts with great sharpness.

TABLE VI.

\begin{tabular}{|c|c|c|c|c|c|c|c|c|c|}
\hline & $\boldsymbol{A}_{3}$. & $A_{4}$. & $A_{5}$ & $A_{6}$. & $\mathrm{B}_{4}$ & $\mathbf{B}_{\tau}$ & $\mathbf{B}_{8}$. & $\mathrm{B}_{3}$ & B . \\
\hline & $\begin{array}{r}69.66 \\
.74 \\
.74 \\
.58 \\
.74 \\
.71 \\
.66 \\
.66 \\
.71 \\
.69 \\
.69 \\
.79 \\
.61 \\
.77\end{array}$ & $\begin{array}{r}69968 \\
\cdot 76 \\
\cdot 71 \\
\cdot 71 \\
\cdot 65 \\
\cdot 76 \\
\cdot 71 \\
\cdot 65 \\
\cdot 63 \\
\cdot 73 \\
\cdot 68 \\
\cdot 76 \\
\cdot 68 \\
\cdot 63\end{array}$ & $\begin{array}{r}69.69 \\
.69 \\
.74 \\
.74 \\
.66 \\
.69 \\
.64 \\
.64 \\
.64 \\
.64 \\
.74 \\
.66 \\
.64 \\
.72\end{array}$ & \begin{tabular}{|r}
69.66 \\
.63 \\
.63 \\
.66 \\
.79 \\
.69 \\
.71 \\
.66 \\
.63 \\
.66 \\
.71 \\
.77 \\
.77 \\
.71
\end{tabular} & $\begin{array}{r}69.75 \\
\cdot 64 \\
\cdot 64 \\
\cdot 70 \\
\cdot 64 \\
\cdot 62 \\
\cdot 64 \\
\cdot 70 \\
.64 \\
\cdot 64 \\
\cdot 64 \\
\cdot 67\end{array}$ & $\begin{array}{r}69.68 \\
.63 \\
.63 \\
.65 \\
.65 \\
.65 \\
.71 \\
.71 \\
.73 \\
.63 \\
.73 \\
.63\end{array}$ & $\begin{array}{r}69.69 \\
.66 \\
\cdot 72 \\
.74 \\
.72 \\
.69 \\
.72 \\
.66 \\
.69 \\
.64 \\
.66 \\
.69\end{array}$ & $\begin{array}{r}69.69 \\
\cdot 66 \\
\cdot 63 \\
.66 \\
\cdot 71 \\
.66 \\
.58 \\
.61 \\
.66 \\
.66 \\
.63 \\
.71\end{array}$ & $\begin{array}{r}69.66 \\
.56 \\
.56 \\
.48 \\
.51 \\
.56 \\
.53 \\
.53 \\
.53 \\
.48 \\
.48 \\
.58\end{array}$ \\
\hline $\begin{array}{l}\text { Mean ........... } \\
\text { Probable error. } \\
\text { Thermometer. }\end{array}$ & $\begin{array}{c}69 \cdot 69 \\
010 \\
2\end{array}$ & $\mid \begin{array}{c}69 \cdot 69 \\
\cdot 008 \\
2\end{array}$ & $\begin{array}{c}69 \cdot 68 \\
.007 \\
2\end{array}$ & $\left|\begin{array}{c}69 \cdot 69 \\
\cdot 009 \\
2\end{array}\right|$ & $\begin{array}{c}69 \cdot 66 \\
\cdot 007 \\
2\end{array}$ & $\mid \begin{array}{c}69 \cdot 67 \\
\cdot 008 \\
2\end{array}$ & $\begin{array}{c}69 \cdot 69 \\
\cdot 006 \\
2\end{array}$ & $\begin{array}{c}69 \cdot 65 \\
\cdot 007 \\
2\end{array}$ & $\mid \begin{array}{c}69 \cdot 54 \\
\cdot 010 \\
3\end{array}$ \\
\hline
\end{tabular}

2. Trichlorceniline.-A was obtained by chlorinating a solution of aniline in glacial acetate, as described under Monochloraniline. The product was meltel under aqueous potash, twice distilled in a current of steam, and crystallized twice from naphtha and thrice \&c. ( $A_{3} \& c$.) from alcohol.

The chlorination of acetanilide suspended in water yields little or no trichloraniline.

Lesimplet describes a modification of trichloraniline which he prepared from nitrotrichlorobenzol by reduction. It has, he states, a very unpleasant and persistent smell, and melts at $96^{\circ} .5$. On these two points my derivative differs from his: it has a faint but not unpleasant odour, and melts at about $77^{\circ}$. In all the other reactions and characters mentioned by Lesimple the two bodies exhibit a complete agreement. Beilstein (who,

* Loc. cit.

† Ann. Chem. Pharm. cxxxrii. pp. 126, 127 . 
subsequently to myself, published an account of the derivative having the lower melting-point) confirms my determination. The substance with which I have dealt seems, then, to be isomeric with Lesimple's. Trichloraniline yields a nonelectric powder, which, in consequence of the woolliness of this body, is rather difficult to obtain. The powder cakes somewhat on drying. The melting-point is exceedingly sharp.

TABLe VII.

\begin{tabular}{|c|c|c|c|c|c|c|c|c|}
\hline & $\boldsymbol{A}_{3}$. & $\mathbf{A}_{1}$ & $A_{5}$. & $\boldsymbol{A}_{6}$. & $A_{\mathrm{T}}$. & $A_{8}$. & $\mathbf{A}_{3}$. & $A_{9}$ \\
\hline & $\begin{array}{r}77.06 \\
.03 \\
.01 \\
.06 \\
.06 \\
.09 \\
.03 \\
.03 \\
.03 \\
.06 \\
.11 \\
.06\end{array}$ & $\begin{array}{c}77.05 \\
.05 \\
.05 \\
.08 \\
.05 \\
.08 \\
.08 \\
.02 \\
.05 \\
.08 \\
.08 \\
.08\end{array}$ & $\begin{array}{r}7 \% \cdot 08 \\
\cdot 05 \\
.05 \\
.08 \\
.08 \\
.08 \\
.08 \\
.05 \\
.05 \\
.05 \\
.05 \\
.05\end{array}$ & $\begin{array}{r}77.06 \\
.03 \\
.03 \\
.09 \\
.06 \\
.06 \\
.01 \\
.06 \\
.06 \\
.09 \\
.03 \\
.03\end{array}$ & $\begin{array}{r}77 \cdot 07 \\
.07 \\
\cdot 07 \\
\cdot 04 \\
\cdot 07 \\
\cdot 10 \\
\cdot 12 \\
\cdot 10 \\
\cdot 10 \\
\cdot 10 \\
\cdot 07 \\
\cdot 10\end{array}$ & $\begin{array}{r}77.03 \\
.03 \\
.03 \\
.06 \\
.06 \\
.03 \\
.06 \\
.03 \\
.03 \\
.06 \\
.03 \\
.06\end{array}$ & $\begin{array}{l}77.02 \\
77.02 \\
77.05 \\
77.07 \\
77.02 \\
77.02 \\
76.99 \\
76.99 \\
77.07 \\
77.05 \\
77.10 \\
77.02\end{array}$ & $\begin{array}{r}77.00 \\
.02 \\
.02 \\
.02 \\
.02 \\
.05 \\
.02 \\
.02 \\
.05 \\
.07 \\
.00 \\
.02\end{array}$ \\
\hline $\begin{array}{l}\text { Mear ............... } \\
\text { Probable error .... } \\
\text { Thermometer }\end{array}$ & $\begin{array}{c}77 \cdot 05 \\
.005 \\
2\end{array}$ & $\begin{array}{c}77 \cdot 06 \\
\cdot 004 \\
2\end{array} \mid$ & $\begin{array}{c}77 \cdot 06 \\
\cdot 003 \\
2\end{array}$ & $\begin{array}{c}77 \cdot 05 \\
\cdot 005 \\
2\end{array}$ & $\begin{array}{l}77 \cdot 08 \\
.004 \\
2\end{array}$ & $\begin{array}{c}77 \cdot 04 \\
.008 \\
2\end{array}$ & $\begin{array}{l}77 \cdot 04 \\
.006 \\
2\end{array}$ & $\begin{array}{c}77.03 \\
.004 \\
3\end{array}$ \\
\hline
\end{tabular}

3. Monobromaniline.-In order to prepare this substance, the best commercial aniline was heated to $100^{\circ}$ for three hours with $\frac{1}{32}$ part of mercuric bromide, which gave rise to the formation of a trace of rosaniline. The liquid was for the most part distilled off, cohobated for twelve hours with an equal weight of glacial acetate, and then distilled to $130^{\circ}$. The residue, after treatment with hot water, and pressure, was powdered finely, and rapidly stirred in a large bulk of water ; into this, 1.75 part of bromine was gradually introduced. The brominated acetanilides thus produced were decomposed with alcoholic potash, and the resulting bromanilines separated by treatment with aqueous hydric chloride. The principal product was dibromaniline.

Specimens $\mathrm{A}$ and $\mathrm{B}$ were obtained by partially attacking with alcoholic potash the mixed bromacetanilides; the unattacked residue yielded no more on renewing the treatment. They were crystallized several times from naphtha and spirit. The remainders of $A$ and $B$ were further crystallized thrice from spirit $(A B)$. The mother-liquids of these preparations 
were united, and their bromaniline crystallized four times from naphtha and nine times from alcohol, in the presence, during the last two operations, of animal charcoal (C). Q was obtained by directly treating aniline with bromine. It was purified by crystallization-once from naphtha and thrice from alcohol with the aid of animal charcoal $\left(Q_{1}\right)$, also once more from alcohol $\left(\mathrm{Q}_{2}\right)$.

Monobromaniline may be dried over oil of vitriol; but I have preferred to use calcic chloride.

The melting-point of bromaniline is very sharp; A B proved exceptionally sudden in this respect.",

TABLE VIII.

\begin{tabular}{|c|c|c|c|c|c|c|c|}
\hline & A. & B. & A B. & $\mathrm{C}_{1}$ & $C_{1}$ & $Q_{1}$ & $Q_{2_{2}}$ \\
\hline & $\begin{array}{r}61.78 \\
.78 \\
.74 \\
.89 \\
.84 \\
.85 \\
.91 \\
.80 \\
.84 \\
.87 \\
.87 \\
.84 \\
.78 \\
.84 \\
\ldots . .\end{array}$ & \begin{tabular}{|r|}
$61 \cdot 78$ \\
.82 \\
.91 \\
.80 \\
.80 \\
.74 \\
.71 \\
.82 \\
.76 \\
.84 \\
.78 \\
.89 \\
.84 \\
$\ldots \ldots$ \\
$\cdots \cdots$
\end{tabular} & $\begin{array}{r}6 \mathrm{i} \cdot 76 \\
.78 \\
.76 \\
.83 \\
.83 \\
.76 \\
.85 \\
.76 \\
.76 \\
.76 \\
.76 \\
.74 \\
.74 \\
.78 \\
\ldots . .\end{array}$ & \begin{tabular}{|r|}
61.82 \\
.86 \\
.76 \\
80 \\
80 \\
.82 \\
.75 \\
.82 \\
.78 \\
.78 \\
.76 \\
.82 \\
.84 \\
.76 \\
$\cdots \cdots$
\end{tabular} & \begin{tabular}{|r|}
61.65 \\
.81 \\
.68 \\
.89 \\
68 \\
.70 \\
.84 \\
.78 \\
.81 \\
.84 \\
.76 \\
.84 \\
.92 \\
.84 \\
.84
\end{tabular} & \begin{tabular}{|r|}
61.93 \\
.85 \\
.74 \\
.88 \\
.90 \\
.88 \\
.72 \\
.85 \\
.77 \\
.88 \\
.79 \\
.79 \\
.88 \\
.85
\end{tabular} & \begin{tabular}{|r}
61.94 \\
.78 \\
.97 \\
.97 \\
.97 \\
.94 \\
.83 \\
.81 \\
.83 \\
.83 \\
.81 \\
.81 \\
.78 \\
.83
\end{tabular} \\
\hline $\begin{array}{l}\text { Mean ............... } \\
\text { Probable error ... } \\
\text { Thermometer ... }\end{array}$ & $\mid \begin{array}{c}61 \cdot 83 \\
.008 \\
4\end{array}$ & $\begin{array}{c}61 \cdot 81 \\
.010 \\
4\end{array}$ & $\left|\begin{array}{c}61 \cdot 78 \\
.006 \\
4\end{array}\right|$ & $\begin{array}{c}61 \cdot 80 \\
\cdot 006 \\
4\end{array}$ & $\begin{array}{c}61 \cdot 79 \\
\cdot 014 \\
2\end{array}$ & $\left|\begin{array}{c}61 \cdot 84 \\
\cdot 011 \\
2\end{array}\right|$ & $\begin{array}{c}61 \cdot 86 \\
.013 \\
2\end{array}$ \\
\hline
\end{tabular}

4. Dibromaniline [see Monobromaniline].-The substance was dissolved in water containing one tenth vol. of common aqueous hydric chloride, the solution filtered cold, and mixed with sufficient ammonia.

Specimens $A$ and $B$ were obtained by the partial action of alcoholic potash on bromacetanilides. A was crystallized four times from naphtha and five times from alcohol; B three times from naphtha, once from spirit, twice from alcohol. $C$ was similarly obtained; it was separated in an evaporation for monobromaniline, having been held in solution by the hydrochloride of that body: this sample was crystallized three times from naphtha and three times from alcohol, and animal charcoal was used. $F$ and $G$ were a result of the further action of alcoholic potash on bromacetanilides. F was sepa- 
rated like $\mathrm{O}$; it was crystallized three times from naphtha, four times from alcohol, and animal charcoal was used. $G$ was treated on five successive occasions with a quantity, insufficient to dissolve it, of the dilute aqueous hydric chloride already named; the cold filtered solution was precipitated with ammonia. Of the successive precipitates $\left(G_{1}, G_{2}, G_{3}, G_{4}, G_{5}\right)$, $G_{1}, G_{3}$, and $G_{5}$ were used for the determination of meltingpoint; $G_{1}$ and $G_{3}$ were crystallized twice from naphtha and thrice from alcohol, animal charcoal being present at the last operation; $G_{5}$ was crystallized twice from naphtha, and twice from alcohol in presence of animal charcoal.

The hydrochloric solution of dibromaniline already mentioned sometimes shows supersaturation.

TABle IX.

\begin{tabular}{|c|c|c|c|c|c|c|c|c|}
\hline & B. & A. & C. & F. & $G_{5}$. & $G_{1}$. & $\mathrm{G}_{3}$. & $G_{3}$. \\
\hline & $\begin{array}{r}78.91 \\
.94 \\
.88 \\
.83 \\
.88 \\
.91 \\
.88 \\
.80 \\
.94 \\
.78 \\
.91 \\
.78 \\
.91 \\
.78\end{array}$ & $\begin{array}{r}78.88 \\
.91 \\
.85 \\
.80 \\
.91 \\
.77 \\
.72 \\
.88 \\
.83 \\
.77 \\
.69 \\
.83 \\
.77 \\
.91\end{array}$ & $\begin{array}{r}78.74 \\
.85 \\
.85 \\
.71 \\
.93 \\
.87 \\
.90 \\
.87 \\
.77 \\
.71 \\
.85 \\
.90 \\
.82 \\
.77\end{array}$ & $\begin{array}{r}78.82 \\
.85 \\
.66 \\
.82 \\
.79 \\
.87 \\
.85 \\
.69 \\
.93 \\
.71 \\
.71 \\
.90 \\
.87 \\
.90\end{array}$ & $\begin{array}{r}78.84 \\
.73 \\
.73 \\
.79 \\
.76 \\
.68 \\
.76 \\
.76 \\
.79 \\
.87 \\
.71 \\
.81 \\
.87 \\
.81\end{array}$ & $\begin{array}{r}78.68 \\
.73 \\
.71 \\
.79 \\
.76 \\
.87 \\
.73 \\
.81 \\
.89 \\
.92 \\
.84 \\
.84 \\
\ldots \ldots . \\
\ldots \ldots .\end{array}$ & $\begin{array}{r}78.79 \\
.79 \\
.79 \\
.76 \\
.82 \\
.90 \\
.74 \\
.82 \\
.92 \\
.90 \\
.82 \\
.74 \\
.92 \\
.82\end{array}$ & $\begin{array}{r}78.92 \\
.85 \\
.92 \\
.81 \\
.81 \\
.73 \\
.73 \\
.83 \\
.94 \\
.85 \\
.79 \\
.85 \\
.79 \\
.92\end{array}$ \\
\hline $\begin{array}{l}\text { Mean .............. } \\
\text { Probable error ... } \\
\text { Thermometer .. }\end{array}$ & $\begin{array}{c}78.87 \\
.010 \\
2\end{array}$ & $\mid \begin{array}{c}78.82 \\
012 \\
2\end{array}$ & $\left|\begin{array}{c}78 \cdot 82 \\
\cdot 013 \\
2\end{array}\right|$ & $\begin{array}{c}78.81 \\
.015 \\
2\end{array}$ & $\begin{array}{c}78 \cdot 78 \\
\cdot 010 \\
2\end{array}$ & $\begin{array}{c}78 \cdot 80 \\
014 \\
2\end{array}$ & $\mid \begin{array}{c}78 \cdot 82 \\
\cdot 011 \\
2\end{array}$ & $\begin{array}{c}78 \cdot 84 \\
\cdot 012 \\
4\end{array}$ \\
\hline
\end{tabular}

5. Tribromaniline [see Monobromaniline].-Sample A was prepared from brominated phenylacetamide by distilling the crude product of the action of alcoholic potash thereon from strong aqueous hydric chloride, and adding water to the distillate.

$\mathrm{Z}$ was precipitated by water from some strongly hydrochloric washings, and crystallized four times from naphtha, four times from alcohol. B was crystallized from a hot mixture of ordinary aqueous hydric chloride diluted with two vols. of water, and washed with the same liquid diluted with six vols. of water. It was crystallized twice from naphtha and twice from alcohol, animal charcoal being present. $Q$ was prepared by directly acting with bromine on aniline dissolved 
in a large volume of dilute sulphuric acid. It is the characteristic product of the reaction; but a little bromaniline is also formed, with traces perhaps of dibromaniline. It was purified by extraction with aqueous hydric chloride diluted with nine vols. of water, by distillation, and by crystallization from spirit with the aid of animal charcoal. $Q_{1}$ was crystallized thrice from spirit, $\mathrm{Q}_{2}$ four times. In the preparation of tribromaniline, whether from aniline directly or from phenylacetamide, the product is accompanied with a considerable amount of a black substance, non-rolatile, and insoluble even in boiling spirit, which evolves much hydric bromide on distillation, and then carbonizes.

The determinations headed $\mathrm{A}, \mathrm{Z}$, and $\mathrm{B}$ were made with a thermometer protected by two glass cylinders; in the other cases the thermometer was bare.

The exact observation of the melting-point of tribromaniline is very difficult, inasmuch as the substance becomes transparent only at the edges of a bead which is for the most part dim and pasty.

TABLE X.

\begin{tabular}{|c|c|c|c|c|c|c|}
\hline & A. & Z. & B. & $Q_{1}$ & $Q_{2}$. & $Q_{1}$ \\
\hline & 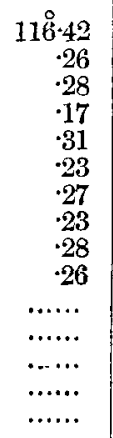 & $\begin{array}{r}116.07 \\
.12 \\
.26 \\
.32 \\
.18 \\
.23 \\
.23 \\
.34 \\
.23 \\
.12 \\
\ldots . . . \\
\ldots \ldots . . \\
\ldots \ldots . . \\
\ldots \ldots . . \\
\ldots \ldots .\end{array}$ & $\begin{array}{r}116.05 \\
.21 \\
.24 \\
.21 \\
.19 \\
.16 \\
.13 \\
.19 \\
.13 \\
.21 \\
\ldots \ldots . . \\
\ldots \ldots . . \\
\ldots \ldots . \\
\ldots \ldots . \\
\ldots \ldots .\end{array}$ & $\begin{array}{r}116.20 \\
\cdot 31 \\
.23 \\
\cdot 15 \\
.26 \\
.31 \\
\cdot 26 \\
.28 \\
.31 \\
.23 \\
.28 \\
.28 \\
.31 \\
.31 \\
.28\end{array}$ & $\begin{array}{r}116.14 \\
\cdot 17 \\
.28 \\
.22 \\
.30 \\
.22 \\
\cdot 19 \\
.22 \\
.36 \\
.36 \\
.33 \\
.28 \\
.36 \\
.30 \\
.39\end{array}$ & $\begin{array}{r}116.31 \\
\cdot 31 \\
\cdot 24 \\
\cdot 24 \\
\cdot 26 \\
\cdot 19 \\
\cdot 11 \\
.31 \\
.31 \\
.26 \\
.29 \\
\cdot 24\end{array}$ \\
\hline $\begin{array}{l}\text { Mean ............... } \\
\text { Probable error ... } \\
\text { Thermometer ... }\end{array}$ & $\begin{array}{c}116.27 \\
.013 \\
2\end{array}$ & $2_{2}^{116 \cdot 21}$ & $\begin{array}{c}116 \cdot 17 \\
2011 \\
2\end{array}$ & $\begin{array}{c}116 \cdot 27 \\
2.008 \\
2\end{array}$ & $\begin{array}{c}116 \cdot 27 \\
2 \\
2\end{array}$ & $\begin{array}{c}116 \cdot 26 \\
3^{\circ}\end{array}$ \\
\hline
\end{tabular}

C. Toluol Derivatives.

1. Nitrotoluol.-Nitrotoluol was prepared from coal-tar toluol, which had been purified by agitation with oil of vitriol and potash successively, and by distillation. According to Beilstein's recommendation, hydric nitrate of spec. grav. 1.48 was dropped into toluol; a stream of air was kept passing through the flask, and a stream of water round it. Through 
the washed mixture of liquid and solid nitrotoluol with toluol thus obtained, a current of steam was passed, to remove toluol first; then a mixture of the two nitrotoluols came over ; and from this the solid was almost completely extracted by solidification in a freezing-mixture and filtering out suddenly by atmospheric pressure. For the success of this operation, distillation in a current of steam is essential.

Sample A was purified by melting with a little Nordhausen, washing with water, and crystallizing from spirit: the motherliquids were evaporated for deposits, $d_{1}, d_{2}, d_{3}$. The results were:-

$d_{1} \cdot$
$51 \cdot 45$
$51 \cdot 11$
$51 \cdot 12$ (recrystallized)
$51 \cdot 13-51 \cdot 52$ (sublimed)

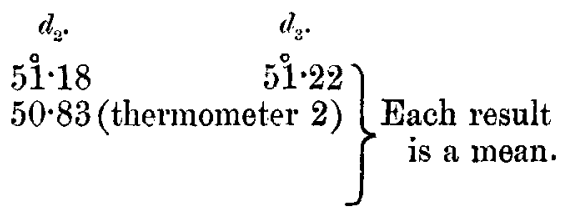

It is clear that neither crystallization from spirit (even after Nordhausen) nor sublimation gives a satisfactory result.

Sample B was purified like $\AA$, twice crystallized from spirit, once from pure high-boiling-point $\left(132^{\circ}\right)$ naphtha, twice from spirit, once from spirit of wine.

Sample C was similarly purified : four successive extracts $(x)$ were taken in a mixture of 1 spirit, 2 water. Therm. 2 . The mean results were:-

$$
\begin{array}{cccc}
x_{1} \cdot & x_{2 \cdot} & x_{3} \cdot & x_{4} \cdot \\
44^{0.5} & 44^{0.9} & 43^{\circ .8} & 50^{\circ .7}
\end{array}
$$

This shows that the method of extracts is also a failure. $x_{1}, x_{2}, x_{3}$ were united as $\mathrm{C}_{a} ; x_{4}$ was set aside as $\mathrm{C}_{b} ; \mathrm{C}_{a}$ was twice crystallized from naphtha, once from spirit of wine. Four similar extracts were then made, united, crystallized from naphtha, $\mathrm{C}_{b}$ added, and the mixture was again crystallized, once from naphtha, once from spirit of wine : this product is termed $\mathrm{C}_{c}$.

Sample D was thrice crystallized from naphtha, once from spirit of wine; twice, thrice, and four times from spirit of wine. Part of the crude substance of $D$ had not been distilled. The fractions are marked $\mathrm{D}_{4}, \mathrm{D}_{5}, \&$ c., according to the times of crystallization.

M was prepared by dropping purified toluol into twice its bulk of nitrous or "fuming" nitrate of spec. grav. 1•48; $50 \mathrm{cub}$. cent. of toluol were added to $100 \mathrm{cub}$. cent. nitrate in each operation, which lasted 1.6 hour. It was crystallized twice from naphtha and thrice from alcohol, 
Dr. E. J. Mills's Researches on Melting-point.

TABLE XI.

\begin{tabular}{|c|c|c|c|c|c|c|c|c|}
\hline & C. & $\mathrm{C}_{\alpha}$ & $\mathbf{C}_{c}$ & $\mathrm{D}_{4}$ & $D_{5}$. & $\mathrm{D}_{6^{*}}$ & $D_{\gamma}$. & $B$. \\
\hline & $\begin{array}{r}51 \cdot 43 \\
\cdot 29 \\
\cdot 40 \\
\cdot 31 \\
\cdot 29 \\
\cdot 31 \\
\cdot 34 \\
\cdot 47 \\
\cdot 31 \\
\cdot 24 \\
\cdot 31 \\
\cdot 21 \\
.31 \\
\cdot 24\end{array}$ & $\begin{array}{r}51 \cdot 39 \\
\cdot 39 \\
\cdot 46 \\
\cdot 37 \\
\cdot 34 \\
\cdot 34 \\
\cdot 24 \\
\cdot 24 \\
\cdot 32 \\
\cdot 21 \\
\cdot 26 \\
\cdot 41 \\
\cdot 26 \\
\cdot 37\end{array}$ & 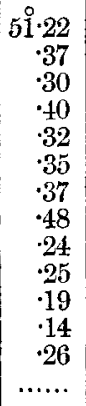 & $\begin{array}{r}51 \cdot 22 \\
.32 \\
.35 \\
.25 \\
.37 \\
.37 \\
.35 \\
.09 \\
.35 \\
.27 \\
.22 \\
.35 \\
.14 \\
\ldots . .\end{array}$ & $\begin{array}{r}51 \cdot 27 \\
\cdot 10 \\
\cdot 10 \\
.35 \\
.37 \\
.35 \\
.35 \\
.27 \\
.39 \\
.39 \\
.27 \\
.39 \\
\ldots \ldots \\
\ldots . .\end{array}$ & \begin{tabular}{|r|}
$51 \cdot 34$ \\
$\cdot 39$ \\
$\cdot 17$ \\
.32 \\
$\cdot 14$ \\
$\cdot 17$ \\
$\cdot 19$ \\
$\cdot 32$ \\
.29 \\
.17 \\
.27 \\
.14 \\
.32 \\
$\ldots \ldots$
\end{tabular} & \begin{tabular}{|r}
$51 \cdot 34$ \\
.39 \\
.24 \\
.39 \\
.39 \\
.34 \\
.39 \\
.39 \\
.30 \\
.32 \\
.36 \\
.30 \\
.22 \\
$\ldots \ldots$
\end{tabular} & $\begin{array}{r}51 \cdot 31 \\
.34 \\
.29 \\
.34 \\
.21 \\
.34 \\
.34 \\
.37 \\
.16 \\
.39 \\
.29 \\
.29 \\
.29 \\
.31\end{array}$ \\
\hline $\begin{array}{l}\text { Mean ........................... } \\
\text { Probable error ... } \\
\text { Thermometer }\end{array}$ & $\begin{array}{c}51 \cdot 32 \\
\cdot 011 \\
2\end{array}$ & $\begin{array}{c}51 \cdot 33 \\
\cdot 013 \\
3\end{array}$ & $\begin{array}{c}51 \cdot 30 \\
\cdot 017 \\
2\end{array}$ & $\begin{array}{c}51.27 \\
.016 \\
2 !\end{array}$ & $\begin{array}{c}51 \cdot 27 \\
.016 \\
3\end{array}$ & $\begin{array}{c}51 \cdot 35 \\
\cdot 016 \\
3\end{array}$ & $\left|\begin{array}{c}51 \cdot 34 \\
\cdot 010 \\
3\end{array}\right|$ & $\begin{array}{c}51 \cdot 30 \\
\cdot 010 \\
2\end{array}$ \\
\hline
\end{tabular}

2. Dinitrotoluol.-I have investigated the melting-point of this substance as prepared (1) directly from toluol, (2) from liquid nitrotoluol ("metanitrotolnol"), (3) solid nitrotoluol when the active masses are relatively small, and (4) solid nitrotoluol when the active masses are relatively large.

[Case I.] Dinitrotoluol was prepared from coal-tar toluol, which had been purified by agitation with oil of vitriol and potash successively, and distillation: a mixture of oil of vitriol with hydric nitrate was used. The product was pressed to free it from oily matter, and crystallized from spirit. The portions that fell successively in the act of crystallization were called A, B, C, D, and many experiments were made with them; but the results were not very accordant. The four samples were firactionally crystallized from spirit: the first deposits being called $A_{1}, B_{1}, \& c$; the second, $A_{2}, B_{2}$, \&c.

Fractions of $F$ (an old preparation) were also employed.

Melting-points having been taken, $\mathrm{C}_{1}, \mathrm{~F}_{4}$, and $\mathrm{F}_{3}$ were found to coincide, and mixed together. Four successive fractions of the mixture were taken; and after some further fractionation,

$$
\begin{aligned}
& \left(\mathrm{F}_{2}\right)_{2},\left(\mathrm{~F}_{1}\right)_{1},\left[\left(\mathrm{~F}_{3} \mathrm{~F}_{4} \mathrm{C}_{1}\right)_{2}\right]_{2},\left[\left(\mathrm{~F}_{3} \mathrm{~F}_{4} \mathrm{C}_{1}\right)_{3}\right]_{2},\left(\mathrm{~F}_{3} \mathrm{~F}_{4} \mathrm{C}_{1}\right)_{1} \\
& \text { yielded } a ; \\
& \left.\mathrm{A}_{1}, \mathrm{~B}_{1},\left(\mathrm{~F}_{2}\right)_{1},\left[\left(\mathrm{~F}_{3} \mathrm{~F}_{4} \mathrm{C}_{1}\right)_{4}\right]_{2},\left[\mathrm{~F}_{3} \mathrm{~F}_{4} \mathrm{C}_{1}\right)_{4}\right]_{1},\left[\left(\mathrm{~F}_{3} \mathrm{~F}_{4} \mathrm{C}_{1}\right)_{3}\right]_{1} \\
& \text { yielded } b ; \\
& \mathrm{A}_{2}, \mathrm{~B}_{2}, \mathrm{C}_{2},\left(\mathrm{~F}_{1}\right)_{2},\left[\left(\mathrm{~F}_{3} \mathrm{~F}_{4} \mathrm{C}_{1}\right)_{2}\right]_{1} \text { yielded } e ; \\
& \mathrm{D}_{\text {yielded } d .}
\end{aligned}
$$


14 Dr. E. J. Mills's Researches on Melting-point.

The following results were then obtained :-

TABLE XII.

\begin{tabular}{|c|c|c|c|c|c|c|c|c|c|}
\hline & $a$. & a. & $b$. & b. & $d$. & $b$. & G. & G. & a. \\
\hline & 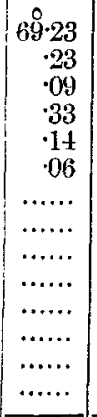 & 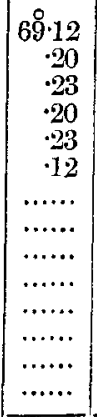 & 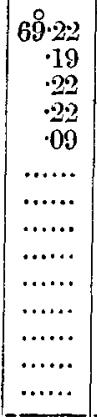 & $\begin{array}{r}69.20 \\
.20 \\
.20 \\
.20 \\
.25 \\
.12 \\
.23 \\
.23 \\
.23 \\
.27 \\
\cdots \ldots . \\
\cdots \cdots \\
\cdots \cdots \\
\cdots \cdots\end{array}$ & $\begin{array}{r}69 \cdot 13 \\
\cdot 16 \\
\cdot 16 \\
\cdot 18 \\
.21 \\
\cdot 10 \\
\cdot 16 \\
.29 \\
.24 \\
.21 \\
\cdot 16 \\
\ldots \ldots . . \\
\ldots \ldots . . \\
\ldots \ldots\end{array}$ & 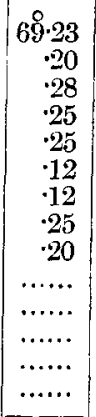 & \begin{tabular}{|r}
69.15 \\
.20 \\
.42 \\
.29 \\
.34 \\
.29 \\
.15 \\
.26 \\
.34 \\
.29 \\
.34 \\
$\ldots \ldots$. \\
$\ldots \ldots$. \\
$\ldots \ldots$.
\end{tabular} & $\begin{array}{r}69.29 \\
.31 \\
\cdot 16 \\
.09 \\
.31 \\
.31 \\
.06 \\
.06 \\
.31 \\
.29 \\
.14 \\
\cdot 29 \\
.31 \\
\cdot 24\end{array}$ & $\begin{array}{r}69.33 \\
\cdot 25 \\
.40 \\
.22 \\
.38 \\
\cdot 28 \\
.33 \\
\cdot 33 \\
\cdot 38 \\
\cdot 17 \\
\cdot 17 \\
\cdot 40\end{array}$ \\
\hline $\begin{array}{l}\text { Mean } \\
\text { Probable error............ } \\
\text { Thermometer... }\end{array}$ & $\begin{array}{c}69 \cdot 18 \\
025 \\
3\end{array}$ & $\left|\begin{array}{c}69 \cdot 18 \\
\cdot 013 \\
3\end{array}\right|$ & $\left|\begin{array}{c}69 \cdot 19 \\
\cdot 015 \\
3\end{array}\right|$ & $\begin{array}{c}69 \cdot 21 \\
.007 \\
3\end{array}$ & $\left|\begin{array}{c}69 \cdot 18 \\
010 \\
3\end{array}\right|$ & $\left|\begin{array}{c}69 \cdot 21 \\
\cdot 012 \\
2\end{array}\right|$ & $\mid \begin{array}{c}69 \cdot 28 \\
\cdot 016 \\
2\end{array}$ & $\begin{array}{c}69 \cdot 23 \\
.017 \\
3\end{array}$ & $\begin{array}{c}69 \cdot 30 \\
\cdot 016 \\
2\end{array}$ \\
\hline
\end{tabular}

[Case II.] The mixture of nitrotoluols obtained by nitrating coal-tar toluol was cooled to $-17^{\circ}$, and the solid modification (which separated in crystals) removed by sudden application of the filter-pump and subsequent fractional distillation. The product boiled at $219^{\circ}-223^{\circ}$. 6.5 cub. cent. of substance dissolved completely in 20 cub. cent. nitrous nitrate, with

TABLE XIII.

\begin{tabular}{|c|c|c|}
\hline & I. & II. \\
\hline & $\begin{array}{r}68.99 \\
69 \cdot 15 \\
\cdot 12 \\
.23 \\
\cdot 20 \\
\cdot 26 \\
\cdot 23 \\
\cdot 20 \\
\cdot 15 \\
\cdot 23 \\
\cdot 26 \\
\cdot 23 \\
\cdot 15 \\
\cdot 15 \\
\cdot 18\end{array}$ & $\begin{array}{r}69 \cdot 24 \\
\cdot 19 \\
.32 \\
\cdot 24 \\
\cdot 21 \\
\cdot 13 \\
\cdot 21 \\
\cdot 16 \\
\cdot 16 \\
.00 \\
\cdot 11 \\
\cdot 19 \\
.03 \\
.08 \\
\cdot 13\end{array}$ \\
\hline $\begin{array}{l}\text { Mean } \\
\text { Probable error } \ldots \ldots \ldots \ldots \ldots \ldots \\
\text { Thermometer } \ldots \ldots \ldots \ldots \ldots \ldots\end{array}$ & $\begin{array}{l}69 \cdot 18 \\
\cdot 012 \\
2\end{array}$ & $\begin{array}{l}69 \cdot 16 \\
\cdot 014 \\
2\end{array}$ \\
\hline
\end{tabular}


slight evolution of heat; after four hours' contact, 150 cub. cent. water were added. The precipitate, which was solid on the following morning, was washed with warm aqueous sodic carbonate, and then weighed about 8.5 grm., or 112.5 per cent., the theoretical yield being $132 \cdot 9$ per cent. I will call this specimen $\mathbf{J}$ dinitrotoluol. It was crystallized four times from naphtha and three times from spirit. (See Table XIII.) [Case III.] The whole of the remainder of D nitrotolnol (p. 12) was treated with nitrous hydric nitrate in the cold; $2.5 \mathrm{grm}$. of the nitrotoluol being dissolved in $39 \mathrm{grm}$. of the nitrate, with which it remained in contact $2 \frac{1}{2}$ hours. The powder was very electric. I will call this specimen L. It was crystallized four times from naphtha and thrice from spirit.

The following numbers were obtained with Therm. 2:-

TABLe XIII a.

\begin{tabular}{|c|c|}
\hline & $\begin{array}{r}69 \cdot 28 \\
\cdot 17 \\
\cdot 20 \\
\cdot 17 \\
\cdot 14 \\
\cdot 12 \\
\cdot 12 \\
\cdot 17 \\
\cdot 22 \\
\cdot 17 \\
\cdot 14 \\
\cdot 03 \\
\cdot 22 \\
.22 \\
.22\end{array}$ \\
\hline 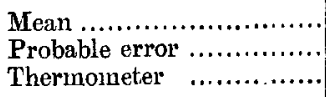 & $\begin{array}{l}69 \cdot 17 \\
.010 \\
2\end{array}$ \\
\hline
\end{tabular}

[Case IV.] When rather larger quantities are taken, though the same proportions between the reagents and time of action be observed, a different result is obtained. Thus Y was prepared from $4.5 \mathrm{grm}$. M mononitrotoluol; the crude product (122 per cent.) was purified by warming with weak aqueous potash containing ammonia, and was crystallized twice from naphtha, eight times from alcohol. Z was made from $20.5 \mathrm{grm}$. of a new stock of solid mononitrotoluol (which had been distilled in steam, frozen, pressed, and crystallized twice from naphtha and four times from alcohol); the crude product (120 per cent.) was crystallized twice from naphtha, and eight to nine times $\left(\mathrm{Z}_{8}, \mathrm{Z}_{9}\right)$ from alcohol. Both samples had a faint yellowish tinge. 
TABLe XIV.

\begin{tabular}{|c|c|c|c|}
\hline & Y. & $\mathbf{Z}_{\triangleleft}$. & $Z_{3}$ \\
\hline & $\begin{array}{r}69.54 \\
\cdot 57 \\
.54 \\
.62 \\
.57 \\
.59 \\
.57 \\
.57 \\
.51 \\
.51 \\
.51 \\
.59\end{array}$ & $\begin{array}{r}69.60 \\
.60 \\
.57 \\
.63 \\
.57 \\
.55 \\
.57 \\
.57 \\
.65 \\
.63 \\
.60 \\
.57\end{array}$ & $\begin{array}{r}69.43 \\
\cdot 46 \\
\cdot 51 \\
\cdot 51 \\
\cdot 38 \\
\cdot 51 \\
\cdot 51 \\
\cdot 56 \\
\cdot 56 \\
\cdot 56 \\
\cdot 62 \\
\cdot 59 \\
\cdot 59\end{array}$ \\
\hline $\begin{array}{l}\text { Mean } \ldots . . . . . . . . . . \\
\text { Probable error } \quad . . \\
\text { Thermometer } \quad . .\end{array}$ & $\begin{array}{c}69 \cdot 56 \\
\cdot 007 \\
2\end{array}$ & $\begin{array}{c}69 \cdot 59 \\
\quad 006 \\
2\end{array}$ & $\begin{array}{c}69 \cdot 52 \\
.013 \\
2\end{array}$ \\
\hline
\end{tabular}

3. Trinitrotoluol.-A. Some crude coal-tar dinitrotoluol was heated with about five times its weight of "fuming" nitrate for more than thirty hours, but not so as to cause ebullition of the liquid. It had lost about 15 per cent. of its weight, but, as shown by its melting-point, had not been converted into trinitrotoluol.- $\mathrm{B}$ was lost in the process of crystallization.-C. The deposit from the nitric mother-liquid of the preparation fused at about $59^{\circ} \cdot 7$. The substance itself fused at about $80^{\circ} .8$ when crystallized nine times from spirit; and then, when kept a few days, its melting-point rose to about $181^{\circ} \cdot 8$. A small residue from the entire preparation, crystallized thrice from spirit, thrice from naphtha, and thrice from spirit of wine, fused at $182^{\circ} .8$ nearly. This body is soluble in naphtha, insoluble in cold and very sparingly soluble in hot spirit, insoluble in water or aqueous ammonia. Quantitative experiment seems to indicate that it is a compound of dinitrotoluol with trinitrotoluol. In appearance it closely resembles trinitrotoluol. Subsequent attempts to prepare it, both directly and in the nascent way, did not succeed.-D. The result of A was confirmed.

E. A specimen of coal-tar trinitrotoluol about 3 years old, yellow at the top ; the melting-point of the lower and colourless part was taken. (This result will be noticed separately.) The remainder from this first determination (part being yellow) was erystallized twice from naphtha and once from spirit of wine. The results are given under the first $\mathrm{E}$ column; the 
Dr. E. J. Mills's Researches on Melting-point.

result of a further crystallization from spirit under the second E column; and so on.

TABLE XV.

\begin{tabular}{|c|c|c|c|c|c|c|c|c|c|c|}
\hline & $F_{1}$ & $F_{1}$. & $F_{1}$. & $\mathbf{F}_{2^{*}}$ & $F_{2^{*}}$ & E. & E. & E. & E. & K. \\
\hline & $\begin{array}{r}78.88 \\
.91 \\
79 \cdot 05 \\
78 \cdot 78 \\
.81 \\
.81 \\
.78 \\
.81 \\
.81 \\
.81 \\
.78 \\
\ldots \ldots .\end{array}$ & $\begin{array}{r}78.86 \\
.91 \\
.81 \\
.86 \\
.73 \\
.78 \\
.78 \\
.84 \\
.73 \\
.81 \\
.81 \\
\ldots . .\end{array}$ & $\begin{array}{r}78.89 \\
.79 \\
.87 \\
.94 \\
.89 \\
.84 \\
.78 \\
.84 \\
.86 \\
.92 \\
.83 \\
\ldots \ldots\end{array}$ & $\begin{array}{r}78 \cdot 78 \\
.88 \\
.80 \\
.88 \\
.88 \\
.90 \\
.93 \\
.93 \\
.80 \\
.88 \\
.93\end{array}$ & $\begin{array}{r}78.85 \\
.85 \\
.83 \\
.93 \\
.80 \\
.87 \\
.93 \\
.93 \\
.92 \\
.92 \\
.83 \\
\ldots . .\end{array}$ & \begin{tabular}{|r}
78.79 \\
.76 \\
.81 \\
-86 \\
.83 \\
889 \\
.65 \\
.83 \\
.89 \\
71 \\
.86 \\
79.02
\end{tabular} & $\begin{array}{r}78.83 \\
.81 \\
.86 \\
.89 \\
.83 \\
.89 \\
.76 \\
.81 \\
.86 \\
.97 \\
.73 \\
.91\end{array}$ & $\begin{array}{r}78.76 \\
.86 \\
773 \\
.62 \\
.78 \\
.78 \\
.78 \\
.88 \\
.78 \\
.83 \\
.78 \\
.86\end{array}$ & $\begin{array}{r}78.88 \\
.78 \\
.80 \\
.70 \\
.88 \\
.82 \\
.85 \\
.80 \\
82 \\
.80 \\
.90 \\
.82\end{array}$ & $\begin{array}{r}78.87 \\
.95 \\
.95 \\
.90 \\
.90 \\
.95 \\
.84 \\
.90 \\
.84 \\
.78 \\
.84\end{array}$ \\
\hline $\begin{array}{l}\text { Mean } . . . . . . . . . . \\
\text { Probahle error. } \\
\text { Thermometer... }\end{array}$ & $\mid \begin{array}{c}78 \cdot 84 \\
0016 \\
2\end{array}$ & $\begin{array}{c}78 \cdot 81 \\
\cdot 011 \\
2\end{array}$ & $\begin{array}{c}78 \cdot 86 \\
.010 \\
\mathbf{3}\end{array}$ & $\begin{array}{c}78 \cdot 87 \\
.011 \\
3\end{array}$ & $\left|\begin{array}{c}78.88 \\
.009 \\
3\end{array}\right|$ & $\left|\begin{array}{c}78.82 \\
\cdot 018 \\
2\end{array}\right|$ & $\begin{array}{c}78 \cdot 81 \\
.012 \\
2\end{array}$ & $\mid \begin{array}{c}78 \cdot 78 \\
.013 \\
2\end{array}$ & $\left|\begin{array}{c}78 \cdot 82 \\
010 \\
2\end{array}\right|$ & $\left|\begin{array}{c}78 \cdot 88 \\
011 \\
2\end{array}\right|$ \\
\hline
\end{tabular}

F. Coal-tar toluol boiling at $109^{\circ} \cdot 5-112^{\circ} \cdot 0$ was purified with oil of vitriol in the cold; it then boiled at $110^{\circ}-113^{\circ}$. Equal volumes (300 cub. cent.) of nitrate (sp. gr. 1.48) and this substance were mixed, the latter being run in gradually. 51 cub. cent. of toluol were recovered by distillation; hence benzol was absent. The product was washed, added to 300 cub. cent. "fuming" nitrate (sp. gr. 1.5) ; washed, added to 4 vols. "fuming" nitrate (the latter), left 24 hours, and 1 vol. Nordhausen poured in-this being done in two operations, on account of the violent action in the cold. The yield was 190.7 per cent.; theory, 246.7 per cent. Half of the yield was crystallized from naphtha and spirit, and termed $F_{1}$. The other half was boiled for $6 \times 6$ hours with "fuming"; nitrate, and termed $\mathrm{F}_{2}$; the product was very dark, contained scarcely any acid bodies, and showed little loss when weighed. The fusion-points of $\mathrm{F}_{1}$ and $\mathrm{F}_{2}$ are the same.

K. Prepared from liquid coal-tar nitrotoluol which had been twice distilled, cooled to $-17^{\circ}$, filtered, again distilled (under $224^{\circ}$ ); when cooled as mentioned, only a trace of crystals was deposited. $19 \mathrm{cub}$. cent. of this liquid, $150 \mathrm{cub}$. cent. "fuming" nitrate, 100 cub. cent. Nordhausen, yielded 31.5 $\mathrm{grm}$, trinitrotoluol, $=142 \cdot 6$ per cent., theory requiring $165 \cdot 7$ per cent. The product was crystallized four times from Plit. Mag. S. 5. Vol. 14. No. 85. July 1882. 
naphtha, five times from spirit; its fusion-point then agreed with that of $\mathrm{F}_{1}$ and $\mathrm{F}_{2}$.

Such trinitrotoluol is found with great ease, an hour's ebullition with a mixture of equal volumes of oil of vitriol and common nitrate sufficing to produce it. Now the presence of oil of vitriol is a great hindrance to making ordinary trinitrotoluol*.

M. M nitrotoluol was treated with Nordhausen and nitrous nitrate, and yielded $157 \cdot 1$ per cent. of product. The meltingpoint of this preparation having been found not quite regular, the substance was again treated with the nitrating-mixture, and crystallized twice from naphtha, and thrice $\left(\mathrm{M}_{1}\right)$, four times $\left(\mathbf{M}_{2}\right)$, \&c. (\&c.) from spirit.

The crystalline form of this modification of trinitrotoluol is distinct from that of $F_{1}$ or $K_{1}$, being much more prismatic and less platy.

A small preparation (L) of trinitrotoluol made from $\mathrm{L}$ dinitrotoluol (itself made from $D$ nitrotoluol) was treated like $M$, and the melting-point also determined before complete nitration had been effected. This point was $78^{\circ} \cdot 91 \pm \cdot 008$, after one crystallization from naphtha and two from spirit; and the prismatic character of the crystals was apparent; but the amount of substance was too little to go on with.

TABLE XVI.

\begin{tabular}{|c|c|c|c|c|c|}
\hline & $\mathbf{M}_{\mathrm{i}}$ & $\mathbf{M}_{2}$ & $\mathbf{M}_{3}$ & $\mathbf{M}_{4}$ & $M_{5}$ \\
\hline & $\begin{array}{r}80 \cdot 49 \\
\cdot 36 \\
\cdot 52 \\
\cdot 49 \\
\cdot 52 \\
\cdot 46 \\
\cdot 49 \\
\cdot 49 \\
\cdot 54 \\
\cdot 54 \\
\cdot 49 \\
\cdot 49 \\
\cdot 52 \\
\cdot 54\end{array}$ & $\begin{array}{r}80 \cdot 53 \\
\cdot 56 \\
\cdot 58 \\
\cdot 42 \\
\cdot 56 \\
.42 \\
\cdot 55 \\
\cdot 53 \\
\cdot 50 \\
\cdot 48 \\
\cdot 61 \\
\cdot 58 \\
\cdot 42 \\
\cdot 42\end{array}$ & $\begin{array}{r}80.50 \\
\cdot 47 \\
.55 \\
.55 \\
.50 \\
\cdot 47 \\
.58 \\
.55 \\
.50 \\
.53 \\
.61 \\
.61 \\
.53 \\
.50\end{array}$ & $\begin{array}{r}80 \cdot 58 \\
\cdot 53 \\
\cdot 47 \\
.50 \\
\cdot 53 \\
.53 \\
.50 \\
.50 \\
\cdot 47 \\
.53 \\
.53 \\
.55 \\
.53 \\
.53\end{array}$ & $\begin{array}{r}80.55 \\
\cdot 52 \\
.55 \\
.47 \\
.60 \\
.58 \\
.55 \\
.55 \\
.52 \\
.58 \\
.58 \\
.55 \\
.60 \\
.58\end{array}$ \\
\hline $\begin{array}{l}\text { Mean } \ldots . . . . . . . . . . . . \\
\text { Probable error } \\
\text { Thermometer } \quad \ldots .\end{array}$ & $\begin{array}{c}80 \cdot 49 \\
\quad 008 \\
2\end{array}$ & $\begin{array}{l}80 \cdot 51 \\
\quad 012 \\
2\end{array}$ & $\begin{array}{l}80 \cdot 53 \\
\quad 008 \\
2\end{array}$ & $\begin{array}{l}80 \cdot 52 \\
\quad .005 \\
2\end{array}$ & $\begin{array}{l}80 \cdot 55 \\
\quad 006 \\
2\end{array}$ \\
\hline
\end{tabular}

* Zeit. Chem. xiii. p. 539. 
Thus it is evident that trinitrotoluol prepared from the solid modification of nitrotoluol is distinct both in form and meltingpoint from the others; it is also more difficult in making.

It deserves to be mentioned that the melting-point of trinitrotoluol appears to undergo a slight change under certain conditions. Thus, a perfectly colourless specimen three years old melted at $78^{\circ} \cdot 76$-the number of observations being 13 , and the probable error 0.012. A few grammes of the specimen $\mathrm{F}_{2}$, after exposure to light, with frequent agitation, for 13 days, during which it became mustard-yellow on the surfaces, melted at $78^{\circ} .78$; the number of observations being 14 , and the probable error 0.013 . This result was obtained after two crystallizations from naphtha and two from spirit, when the substance had become brilliantly white.

\section{Toluidine Derivatives.}

Toluidine.-The modification examined is solid at the ordinary temperature, and obtainable by the reduction of mononitrotoluol.

Sample $H$ was purchased from Messrs. Hopkin and Williams. It was purified by conversion into oxalate, which salt was thrice extracted by ether and then decomposed by potash, distillation in a current of steam, and crystallization thrice from naphtha and four times \&c. $\left(\mathrm{H}_{4}\right.$ \&c. $)$ from alcohol.

$\mathrm{S}$ was given me by $\mathrm{Mr}$. Spiller. It was pressed and crystallized twice from naphtha and four to five times $\left(S_{4-5}\right)$ from alcohol.

G was purchased from Dr. Schuchardt, of Görlitz. It was pressed, and crystallized twice from naphtha and three to four times from alcohol $\left(\mathrm{G}_{3-4}\right)$.

The above were ascertained to be all different preparations.

The melting-point of toluidine is difficult to observe. The substance remains for some time in the pasty stage, and then conducts heat very badly; from this cause the melting-point may easily be overestimated. On the other hand, when the solid substance is plunged into a bath which is hotter than the real melting-point, it melts with great readiness and sharpness. Good numbers can only be obtained with finely-powdered material ; the capillary tubes must be introduced into the bath at $4^{\circ}$ or $5^{\circ}$ below the melting-point; and the mercury in the thermometer must rise very slowly towards the last. 


\section{TABLE XVII.}

\begin{tabular}{|c|c|c|c|c|c|c|c|c|c|}
\hline & $\mathrm{H}_{4}$ & $\mathrm{H}_{5}$. & $\mathrm{H}_{6}$. & $\mathrm{H}_{6}$. & $\mathbf{S}_{4}$. & $S_{5}$ & $\mathbf{s}_{6}$ & $\mathrm{G}_{3}$. & $G_{t}$. \\
\hline & $\begin{array}{r}42 \cdot 78 \\
.88 \\
.73 \\
.76 \\
.78 \\
65 \\
.83 \\
.78 \\
.83 \\
.83 \\
.70 \\
.73 \\
\ldots \ldots \\
\ldots \ldots\end{array}$ & $\begin{array}{r}49.79 \\
.74 \\
.61 \\
.77 \\
.71 \\
.66 \\
.69 \\
.77 \\
.71 \\
.69 \\
.63 \\
.79 \\
.63 \\
.77\end{array}$ & $\begin{array}{r}42.78 \\
.67 \\
.73 \\
.76 \\
.70 \\
.83 \\
.70 \\
.73 \\
.78 \\
.83 \\
.65 \\
.70 \\
.76 \\
.62\end{array}$ & $\begin{array}{r}42 \cdot 69 \\
\cdot 85 \\
755 \\
73 \\
73 \\
.69 \\
.75 \\
.81 \\
69 \\
.73 \\
.79 \\
777 \\
73 \\
.81\end{array}$ & $\begin{array}{r}42.82 \\
.82 \\
.82 \\
.82 \\
.72 \\
.74 \\
.87 \\
.82 \\
.74 \\
.84 \\
.74 \\
.72 \\
.69 \\
.82\end{array}$ & $\begin{array}{r}42.81 \\
.86 \\
.83 \\
.76 \\
.79 \\
.83 \\
.76 \\
.83 \\
.79 \\
.68 \\
.71 \\
.83 \\
.81 \\
.79\end{array}$ & $\begin{array}{r}42.80 \\
.76 \\
.74 \\
.76 \\
.71 \\
.68 \\
.36 \\
.86 \\
.81 \\
.76 \\
.78 \\
.66 \\
.67 \\
.76\end{array}$ & $\begin{array}{r}4.9 .67 \\
.80 \\
.72 \\
.83 \\
.75 \\
.77 \\
.85 \\
.75\end{array}$ & $\begin{array}{r}4.983 \\
.78 \\
.75 \\
.80 \\
.83 \\
.93 \\
.78 \\
.80\end{array}$ \\
\hline $\begin{array}{l}\text { Mean } \ldots . . . . . . . . \\
\text { Probable error. } \\
\text { Thermometer... }\end{array}$ & $\left|\begin{array}{c}42 \cdot 77 \\
012 \\
2\end{array}\right|$ & $\begin{array}{c}42 \cdot 71 \\
.011 \\
2\end{array}$ & $\left|\begin{array}{c}42 \cdot 73 \\
.011 \\
2\end{array}\right|$ & $\begin{array}{c}42 \cdot 76 \\
.009 \\
4\end{array}$ & $\begin{array}{c}42 \cdot 78 \\
\cdot 010 \\
2\end{array}$ & $\begin{array}{c}42 \cdot 79 \\
\cdot 009 \\
2\end{array}$ & $\begin{array}{c}42 \cdot 76 \\
\cdot 011 \\
2\end{array}$ & $\begin{array}{c}42 \cdot 77 \\
\cdot 013 \\
3\end{array}$ & $\begin{array}{c}42 \cdot 81 \\
\cdot 01 \\
3\end{array}$ \\
\hline
\end{tabular}

\section{E. Phenol Derivatives.}

1. $\alpha$ Mononitrophenol.-By $\alpha$ mononitrophenol I mean the more volatile mononitrophenol of the two produced by treating phenol with water and nitrate according to Fritsche's method (Journ. prak. Chem. lxxv. p. 257). The crude stock was several times distilled.

A was crystallized from water and dried over oil of vitriol (as the rest were): it had been exposed to light $\left(A_{1}\right)$; it was further and continuously exposed to light $\left(A_{2}\right)$. $B_{1}$ was a partial precipitate from spirit by water, dried in the shade; the mother-liquid gave with more water a precipitate which turned brown when dried like $B_{1}$, and then melted about $0^{\circ} \cdot 6$ below $\mathrm{B}_{1}$. $\mathrm{C}_{1}$ was made like $\mathrm{B}_{1}$, except that scarcely any thing was left in the mother-liquid. E was a total precipitate from a sodic salt which contained, as a mean of two experiments, $14 \cdot 28$ per cent. of sodium (theoretically $14 \cdot 31$ ): it was dried in the shade. D was twice crystallized, probably from weak spirit, and dried in shade twenty days, $i . e$. very much longer than either of the others.

The powder of $\alpha$ mononitrophenol has a tendency to cake together on keeping. 
TABLE XVIII.

\begin{tabular}{|c|c|c|c|c|c|c|}
\hline & D. & $B_{1}$ & $\mathrm{C}_{1}$ & E. & $A_{1}$. & $A_{2}$ \\
\hline & $\begin{array}{r}9 . \\
4.31 \\
.29 \\
.24 \\
.33 \\
.24 \\
.29 \\
.37 \\
.37 \\
.33 \\
.24 \\
.33 \\
\ldots \ldots\end{array}$ & $\begin{array}{r}44 \cdot 29 \\
\cdot 29 \\
\cdot 24 \\
\cdot 18 \\
\cdot 32 \\
\cdot 26 \\
\cdot 29 \\
\cdot 32 \\
\cdot 21 \\
\cdot 32 \\
\cdot 21\end{array}$ & $\begin{array}{r}4 . \cdot 29 \\
\cdot 24 \\
\cdot 18 \\
\cdot 10 \\
\cdot 29 \\
\cdot 29 \\
\cdot 29 \\
\cdot 21 \\
\cdot 29 \\
\cdot 29 \\
\cdot 29\end{array}$ & $\begin{array}{r}44.22 \\
.25 \\
.25 \\
\cdot 22 \\
.27 \\
.27 \\
.30 \\
.22 \\
.27 \\
.25 \\
\ldots \ldots\end{array}$ & $\begin{array}{r}9.28 \\
\cdot 25 \\
\cdot 31 \\
\cdot 28 \\
\cdot 28 \\
\cdot 23 \\
\cdot 28 \\
\cdot 31 \\
\cdot 31 \\
\cdot 28 \\
\cdot 28\end{array}$ & $\begin{array}{r}44.31 \\
\cdot 31 \\
-23 \\
\cdot 17 \\
\cdot 25 \\
.39 \\
\cdot 31\end{array}$ \\
\hline $\begin{array}{l}\text { Mean .............. } \\
\text { Probable error ... } \\
\text { Thermometer ... }\end{array}$ & $\begin{array}{l}44 \cdot 30 \\
\quad 009 \\
2\end{array}$ & $\begin{array}{c}44 \cdot 27 \\
\quad .010 \\
3\end{array}$ & $\begin{array}{c}4425 \\
\quad 012 \\
3\end{array}$ & $\begin{array}{l}44 \cdot 25 \\
\quad .005 \\
2\end{array}$ & $\begin{array}{l}44 \cdot 28 \\
\quad \cdot 005 \\
3\end{array}$ & $\begin{array}{l}44 \cdot 28 \\
\quad 017 \\
3\end{array}$ \\
\hline
\end{tabular}

2. $\beta$ Mononitrophenol. $-\beta$ mononitrophenol is the less volatile mononitrophenol of the two produced by Fritsche's process (Journ. prak. Chem. lxxv. p. 257). The crude stock was converted into sodic salt, washed with aqueous sodic hydrate, dissolved in water, and precipitated by hydric chloride: a sodic salt prepared from this contained $14 \cdot 17$ instead of $14 \cdot 31$ per cent. of sodium, the preparation being effected with but very little loss.

$A_{1}$ was crystallized thrice from naphtha and once from water; $A_{2}$ was the same, twice crystallized from water; $B_{1}$, $B_{2}, B_{3}$ were all crystallized together thrice from naphtha, in one quantity; and this was crystallized thrice from water. All the specimens were dried over oil of vitriol in the dark for about two months.

$\beta$ mononitrophenol becomes pale dirty yellow on exposure to light for a day, especially if a part of it has been melted. As the coloured product probably melts below the temperature at which the uncoloured substance does; and as a broad gasflame must tend somewhat to produce the saine effect as daylight, the long stage of incipient fusion and the uncertainty of the limit are accounted for. 
TABLE XIX.

\begin{tabular}{|c|c|c|c|c|c|}
\hline & $\Delta_{1}$. & $A_{2}$ & $B_{1}$ & $\mathrm{~B}_{2}$ & $\mathrm{~B}_{3}$ \\
\hline & $\begin{array}{r}111.29 \\
.29 \\
.35 \\
.40 \\
.38 \\
.45 \\
.40 \\
.31 \\
.26 \\
.24 \\
\ldots \ldots . . \\
\ldots \ldots\end{array}$ & 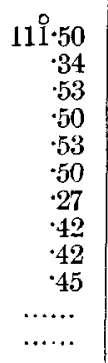 & $\begin{array}{r}111 \cdot 37 \\
.60 \\
.51 \\
.41 \\
.41 \\
.48 \\
.37 \\
.51 \\
.58 \\
.46 \\
.51 \\
.32\end{array}$ & $\begin{array}{r}111.53 \\
.41 \\
.32 \\
.34 \\
.39 \\
.46 \\
.41 \\
.41 \\
.44 \\
.37 \\
\ldots . .\end{array}$ & $\begin{array}{r}111 \cdot 40 \\
\cdot 35 \\
\cdot 40 \\
.40 \\
\cdot 47 \\
.51 \\
.51 \\
.51 \\
.49 \\
.38 \\
.31\end{array}$ \\
\hline $\begin{array}{l}\text { Mean } \\
\text { Probable error } \quad . . \\
\text { Thermometer } \quad \ldots .\end{array}$ & $\begin{array}{c}111 \cdot 34 \\
.014 \\
3\end{array}$ & $\begin{array}{c}111 \cdot 45 \\
.017 \\
2\end{array}$ & $\begin{array}{c}111 \cdot 46 \\
.016 \\
3\end{array}$ & $\begin{array}{c}111 \cdot 41 \\
.012 \\
3\end{array}$ & $\begin{array}{c}111 \cdot 43 \\
.014 \\
3\end{array}$ \\
\hline
\end{tabular}

3. a Dinitrophenol.- $\alpha$ dinitrophenol appears to have been first observed by Armstrong, who, however, did not obtain it in a state of purity; the exacter definition of the substance is due to Hübner and Schneider (Zeit. Chem. xiv. p. 524). In preparing it, I followed the mothod recommended by the lastnamed chemists, depending more especially on the insolubility of the baric derivative in boiling spirit of 90 per cent. When the baric derivative was dissolved in water and treated with aqueous hydric chloride, the hydric salt was precipitated: this was afterwards dissolved and crystallized.

$\boldsymbol{\alpha}$ dinitrophenol bas an extremely pale yellow colour when crystallized from naphtha or spirit; the powder has a deeper shade; and the solution imparts a dark-orange tint to a tissue on which it has been dried.

A, B, C, D, E were distinct preparations. A and B had been crystallized thrice from naphtha and thrice from spirit; $\mathrm{C}$ had been crystallized from water, aqueous potassic chloride, and twice from spirit; D had been made from a baric salt twice extracted with spirit, after which it was crystallized once from naphtha and four times from spirit*; $\mathrm{E}$ was formed by uniting the remainders of $\mathrm{A}, \mathrm{B}$, and $\mathrm{C}$, extracting the baric salt thrice with alcohol, and crystallizing the resulting $\alpha$ dinitrophenol once from naphtha and once from spirit.

* The hot alcoholic solution was poured off from a red, quite insoluble foreign substance. 
a dinitrophenol melts sharply, the pasty stage being short. According to Hübner and Schneider its melting-point is 63-64.

TABle XX.

\begin{tabular}{|c|c|c|c|c|c|c|c|}
\hline & A. & A. & B. & B. & C. & D. & E. \\
\hline & $\begin{array}{r}61.89 \\
.80 \\
.82 \\
.80 \\
.74 \\
.89 \\
.87 \\
.74 \\
.74 \\
.73 \\
.70 \\
.73 \\
\ldots \ldots \\
\ldots \ldots\end{array}$ & $\begin{array}{r}61.79 \\
.79 \\
.84 \\
.82 \\
.74 \\
.87 \\
.87 \\
.84 \\
.87 \\
.92 \\
.74 \\
.79 \\
\ldots \ldots . . \\
\cdots \cdots\end{array}$ & $\begin{array}{r}61.85 \\
.77 \\
.77 \\
.80 \\
.82 \\
.80 \\
\cdot 77 \\
774 \\
.82 \\
.74 \\
.85 \\
.80 \\
.74 \\
.77\end{array}$ & $\begin{array}{r}61.82 \\
.77 \\
.78 \\
.75 \\
.67 \\
.78 \\
.80 \\
.77 \\
.82 \\
.78 \\
.71 \\
.65 \\
.78 \\
.80\end{array}$ & $\begin{array}{r}61.78 \\
.75 \\
.70 \\
.73 \\
.67 \\
.81 \\
70 \\
.75 \\
.75 \\
75 \\
.78 \\
.70 \\
.78 \\
.81\end{array}$ & $\begin{array}{r}61.82 \\
.85 \\
.87 \\
.74 \\
.77 \\
.71 \\
774 \\
.79 \\
.85 \\
74 \\
.74 \\
.85 \\
.82 \\
.82\end{array}$ & $\begin{array}{r}61.79 \\
774 \\
77 \\
.75 \\
.72 \\
.83 \\
.85 \\
.79 \\
.77 \\
.77 \\
775 \\
.75 \\
.70 \\
.77\end{array}$ \\
\hline $\begin{array}{l}\text { Mean } \\
\text { Probable error .... } \\
\text { Thermometer } \quad \ldots\end{array}$ & $\mid \begin{array}{c}61 \cdot 79 \\
.013 \\
4\end{array}$ & $\begin{array}{c}61 \cdot 8 \cdot 2 \\
\cdot 010 \\
2\end{array}$ & $\begin{array}{c}61 \cdot 79 \\
\cdot 006 \\
2\end{array}$ & $\left|\begin{array}{c}61 \cdot 76 \\
.009 \\
4\end{array}\right|$ & $\begin{array}{l}61 \cdot 75 \\
\cdot 007 \\
2\end{array}$ & $\begin{array}{c}61 \cdot 79 \\
\cdot 009 \\
2\end{array} \mid$ & $\begin{array}{c}61 \cdot 77 \\
.007 \\
4\end{array}$ \\
\hline
\end{tabular}

4. $\beta$ Dinitrophenol.--Z. The crude compound was prepared by Grüner's method, from crystalline phenol. A considerable amount of its baric salt was crystallized repeatedly from a large volume of water, and the cooled and filtered mother-liquid precipitated with hydric chloride.

$\mathrm{Z}_{\mathrm{e}}$ was the tenth precipitate; it was crystallized thrice from water.

$Z_{\zeta}$ was the eleventh precipitate; it was crystallized once from water.

$Z_{\eta}$ was the twelfth precipitate; it was crystallized once from water.

Preliminary determinations of melting-point were made with the nine preceding fractions ; but the numbers were not sufficiently satisfactory to warrant proceeding with purification.

$\mathrm{Y}$ was made by Dr. Armstrong from trinitrophenol, by way of amido-dinitrophenol; it was crystallized thrice from water.

T. For this also I am indebted to Dr. Armstrong: he had prepared it by acting with ordinary hydric nitrate on phenol. It was crystallized once from naphtha, once from alcohol, and four times from water. 
In determining the melting-points of $\mathrm{Z}_{\eta}, \mathrm{Z}_{\zeta}$, and $\mathrm{Y}$, the thermometers were protected by two glass cylinders; in the other three cases the cylinders were not used.

Crystallization, powdering, desiccation, and filling of capillary tubes had to be effected either in total darkness or in a deep shade. $\beta$ dinitrophenol is very nearly white; but by two hours' exposure to a somewhat gloomy atmosphere it becomes deep turmeric yellow.

$\beta$ dinitrophenol melts with moderate sharpness.

\section{TABLe XXI.}

\begin{tabular}{|c|c|c|c|c|c|c|}
\hline & $Z_{\eta}$ & $z_{\zeta}$. & $\mathbf{Y}$. & T. & $Z_{e}$ & $Z_{\epsilon}$. \\
\hline & $\begin{array}{r}11660 \\
60 \\
.46 \\
.52 \\
.55 \\
.63 \\
.46 \\
.43 \\
.52 \\
.63\end{array}$ & $\begin{array}{r}111.63 \\
.63 \\
.49 \\
.58 \\
.63 \\
.60 \\
.58 \\
.68 \\
.52 \\
.55\end{array}$ & $\begin{array}{r}111 \cdot 46 \\
.57 \\
69 \\
68 \\
.82 \\
.60 \\
.49 \\
.57 \\
.60 \\
.57\end{array}$ & $\begin{array}{r}111.57 \\
.57 \\
.49 \\
.60 \\
.57 \\
.60 \\
.57 \\
.52 \\
.54 \\
.54\end{array}$ & $\begin{array}{r}1 \mathrm{o} \cdot 66 \\
.64 \\
.61 \\
.61 \\
.64 \\
.80 \\
.61 \\
.66 \\
.53 \\
.66\end{array}$ & $\begin{array}{r}111.65 \\
.55 \\
.65 \\
.58 \\
.53 \\
.63 \\
.60 \\
.58 \\
.53 \\
.65\end{array}$ \\
\hline $\begin{array}{l}\text { Mean ................... } \\
\text { Probable error } \\
\text { Thermometer } \ldots\end{array}$ & $\begin{array}{c}111 \cdot 54 \\
.015 \\
2\end{array}$ & $\begin{array}{c}111 \cdot 59 \\
\cdot 012 \\
2\end{array}$ & $\begin{array}{c}111 \cdot 60 \\
\quad \cdot 020 \\
2\end{array}$ & $\begin{array}{c}111 \cdot 56 \\
.007 \\
2\end{array}$ & $\begin{array}{c}111 \cdot 64 \\
\cdot 014 \\
2\end{array}$ & $\begin{array}{c}111.59 \\
-010 \\
3\end{array}$ \\
\hline
\end{tabular}

5. Trinitrophenol.--Sample A was a commercial specimen. It was crystallized twice from water, once from alcohol, and again from water.

$Z$ was prepared from dinitrophenol made by Grüner's process (v. suprà); the material employed was very pure, having been precipitated from a 12 th $\left(Z_{n}\right)$ cold aqueous extract of the crude basic salt. This was evaporated to dryness on the water-bath with a very large excess of hydric nitrate, and crystallized once from naphtha, once from ethylic alcohol, and twice from water.

$O$ was made from phenol, containing minute amounts of the two modifications of dinitruphenol, by evaporation, as with $Z$. It was crystallized thrice from water, once from alcohol, and a first $\left(\mathrm{O}_{2}\right)$, second $\left(\mathrm{O}_{2}\right)$, and third $\left(\mathrm{O}_{3}\right)$ time from water.

M was similarly prepared from sodic $\alpha$ nitrophenate $(E$ under $\propto$ nitrophenol), and was crystallized thrice from water.

$F$ was derived from sodic $\beta$ nitrophenate (the analysis is 
given under $\beta$ mononitrophenol); it was crystallized once from water, once from alcohol, and again from water.

$\mathrm{N}$ was prepared from some a (Hübner's) dinitrophenol, for which I am indebted to Prof. Armstrong. This was purified by Hübner's two processes, and can have contained at most mere traces of its isomer. The trinitro-compound was crystallized thrice from water.

Trinitrophenol is a nearly white substance when in crystals; if very finely divided by any means, it appears a pale yellow. The powdered crystals, if exposed for two hours to indirect light on a dull morning, acquire a deep mustard-yellow colour. The crystals of the substance termed $\mathrm{N}$ were almost perfectly white.

The melting-point of trinitrophenol is, on the whole, not difficult to observe.

Table XXII.

\begin{tabular}{|c|c|c|c|c|c|c|c|c|c|}
\hline & A. & Z. & $\mathrm{O}_{1}$ & $\mathrm{O}_{2}$ & $\mathrm{O}_{3}$ & M. & F. & N. & N. \\
\hline & $\begin{array}{r}12 i \cdot 11 \\
\cdot 06 \\
08 \\
.11 \\
.03 \\
.06 \\
.03 \\
.06 \\
.24 \\
120.97\end{array}$ & $\begin{array}{l}120 \cdot 95 \\
120.92 \\
121 \cdot 03 \\
120.95 \\
121.06 \\
121 \cdot 00 \\
120.98 \\
121 \cdot 20 \\
121.00 \\
121 \cdot 00\end{array}$ & $\begin{array}{r}121 \cdot 04 \\
.07 \\
.01 \\
.15 \\
.18 \\
.12 \\
.23 \\
.09 \\
.12 \\
.09\end{array}$ & $\begin{array}{r}121 \cdot 14 \\
121 \cdot 11 \\
120.97 \\
121 \cdot 14 \\
120.97 \\
121.06 \\
.14 \\
.09 \\
.09 \\
\cdot 11\end{array}$ & $\begin{array}{r}121.03 \\
120.98 \\
120.98 \\
121.08 \\
.00 \\
.08 \\
.06 \\
.14 \\
.11 \\
.06\end{array}$ & $\begin{array}{r}120 \cdot 99 \\
121 \cdot 13 \\
\cdot 16 \\
\cdot 18 \\
\cdot 10 \\
.16 \\
.19 \\
.07 \\
.19 \\
\cdot 16\end{array}$ & $\begin{array}{r}121 \cdot 20 \\
121 \cdot 17 \\
120.98 \\
121 \cdot 14 \\
.09 \\
.01 \\
.12 \\
.04 \\
.14 \\
120 \cdot 98\end{array}$ & $\begin{array}{r}121 \cdot 20 \\
120.98 \\
121.09 \\
\cdot 12 \\
.12 \\
\cdot 15 \\
.12 \\
\cdot 12 \\
\cdot 15 \\
.17\end{array}$ & $\begin{array}{l}121 \cdot 09 \\
120 \cdot 89 \\
121 \cdot 09 \\
120 \cdot 94 \\
121 \cdot 11 \\
121 \cdot 11 \\
121 \cdot 14 \\
120 \cdot 94 \\
120 \cdot 99 \\
121 \cdot 07\end{array}$ \\
\hline $\begin{array}{l}\text { Mean ............ } \\
\text { Probable error. } \\
\text { Thermometer... }\end{array}$ & $\begin{array}{c}121 \cdot 07 \\
.014 \\
2\end{array}$ & $\begin{array}{c}121 \cdot 01 \\
016 \\
2\end{array}$ & $\begin{array}{c}121 \cdot 11 \\
\cdot 013 \\
2\end{array}$ & $\begin{array}{c}121 \cdot 08 \\
013 \\
2\end{array}$ & $\begin{array}{c}121 \cdot 05 \\
011 \\
2\end{array}$ & $\begin{array}{c}121 \cdot 13 \\
\cdot 013 \\
2\end{array}$ & $\begin{array}{c}121.09 \\
.016 \\
2\end{array}$ & $\mid \begin{array}{c}121 \cdot 12 \\
.012 \\
2\end{array}$ & $\begin{array}{c}121 \cdot 04 \\
\cdot 018 \\
3\end{array}$ \\
\hline
\end{tabular}

\section{F. Naphthalin Derivatives.}

Naphthalin.-Commercial pure naphthalin, which had been twice sublimed, was digested for a few hours with strong oil of vitriol in the water-bath. After washing with water, it was distilled from caustic soda in a current of steam. The first portion of the distillate is termed $A$, the second $B$. These portions were crystallized twice from naphtha and thrice $\left(A_{3}\right.$ \&c.) from alcohol. Before naphthalin melts it exhibits a deciderl pasty stage; yet the melting-point is sufficiently sharp.

The powdered substance is highly electric. 
TABLE XXIII.

\begin{tabular}{|c|c|c|c|c|c|c|c|}
\hline & $A_{3}$ & $A_{4}$ & $A_{5}$ & $A_{6}$ & $\mathbf{B}_{*}$ & $\mathrm{~B}_{\tilde{a}^{*}}$ & $\mathbf{B}_{\varepsilon^{*}}$ \\
\hline & $\begin{array}{l}80 \cdot 06 \\
79 \cdot 98 \\
80 \cdot 01 \\
79 \cdot 95 \\
80 \cdot 03 \\
80 \cdot 06 \\
80 \cdot 09 \\
80.06 \\
80 \cdot 03 \\
79.98 \\
80 \cdot 06 \\
80.03\end{array}$ & $\begin{array}{r}80 \cdot 03 \\
.06 \\
.08 \\
.00 \\
.00 \\
.00 \\
.08 \\
.06 \\
.11 \\
.03 \\
.11 \\
.00\end{array}$ & $\begin{array}{r}80.01 \\
.06 \\
.09 \\
.06 \\
.09 \\
.06 \\
.12 \\
.12 \\
.06 \\
.09 \\
.06 \\
.01\end{array}$ & $\begin{array}{r}80.03 \\
.08 \\
.00 \\
.08 \\
.08 \\
.08 \\
.08 \\
.11 \\
.11 \\
.06 \\
.06 \\
.08\end{array}$ & $\begin{array}{r}80.05 \\
.05 \\
.05 \\
.05 \\
.05 \\
.07 \\
.07 \\
.05 \\
.07 \\
.07 \\
.07 \\
.07\end{array}$ & $\begin{array}{r}80^{\circ} \cdot 05 \\
.08 \\
.05 \\
.02 \\
.08 \\
.05 \\
.08 \\
.08 \\
.05 \\
.05 \\
.10 \\
.05\end{array}$ & $\begin{array}{r}80.06 \\
.14 \\
.09 \\
.09 \\
.09 \\
.09 \\
.03 \\
.09 \\
.09 \\
.09 \\
.11 \\
.03\end{array}$ \\
\hline $\begin{array}{l}\text { Mean ................. } \\
\text { Probable error ... } \\
\text { Thermolneter } \quad \ldots\end{array}$ & $\mid \begin{array}{c}80 \cdot 03 \\
\cdot 008 \\
2\end{array}$ & $\begin{array}{c}80 \cdot 05 \\
\cdot 008 \\
2\end{array}$ & $\mid \begin{array}{c}80 \cdot 07 \\
.007 \\
2\end{array}$ & $\begin{array}{c}80 \cdot 07 \\
\cdot 006 \\
2\end{array}$ & $\begin{array}{c}80 \cdot 06 \\
.002 \\
2\end{array}$ & $\begin{array}{c}80 \cdot 06 \\
004 \\
2\end{array}$ & $\begin{array}{l}80 \cdot 08 \\
.006 \\
2\end{array}$ \\
\hline
\end{tabular}

Nitronaphthalin.-A was a sample which had been in my collection for some years, and the details of its preparation are unknown. It was distilled in steam, and crystallized twice from naphtha and thrice \&c. ( $A_{3} \& c$.) from alcohol.

$B$ was a similar sample from the same source. It was purified and fractionated exactly in the same way as A.

Nitronaphthalin becomes sensibly yellowed by continued exposure to light. It melts with considerable sharpness.

TABle XXIV.

\begin{tabular}{|c|c|c|c|c|c|c|c|c|}
\hline & $A_{3}$. & $A_{4}$ & $A_{5}$. & $A_{6}$. & $\Delta_{\gamma}$ & $\mathrm{B}_{4}$ & $\mathrm{~B}_{5}$ & $\mathrm{~B}_{\bar{\sigma}}$ \\
\hline & $\begin{array}{r}5 \circ \cdot 17 \\
\cdot 20 \\
\cdot 14 \\
.20 \\
\cdot 17 \\
.20 \\
\cdot 17 \\
\cdot 17 \\
\cdot 17 \\
.20 \\
.22 \\
.21 \\
.20 \\
.20\end{array}$ & $\begin{array}{r}50 \cdot \cdot 16 \\
\cdot 13 \\
\cdot 21 \\
\cdot 16 \\
\cdot 16 \\
\cdot 21 \\
\cdot 16 \\
\cdot 16 \\
\cdot 16 \\
\cdot 16 \\
\cdot 21 \\
.21 \\
.25 \\
\cdot 21\end{array}$ & $\begin{array}{r}56 \cdot 17 \\
\cdot 14 \\
.12 \\
\cdot 17 \\
\cdot 29 \\
.22 \\
\cdot 17 \\
\cdot 17 \\
\cdot 14 \\
\cdot 14 \\
\cdot 16 \\
.22 \\
.25 \\
.22\end{array}$ & $\begin{array}{r}56.21 \\
.21 \\
.16 \\
.16 \\
.18 \\
.26 \\
.21 \\
.16 \\
.13 \\
.16 \\
.24 \\
.16 \\
.16 \\
.18\end{array}$ & $\begin{array}{r}56.15 \\
\cdot 15 \\
\cdot 18 \\
-20 \\
.07 \\
\cdot 15 \\
\cdot 12 \\
\cdot 26 \\
\cdot 14 \\
\cdot 10 \\
.18 \\
.23 \\
.18 \\
\cdot 20\end{array}$ & $\begin{array}{r}56.24 \\
.24 \\
\cdot 19 \\
\cdot 19 \\
\cdot 11 \\
\cdot 16 \\
\cdot 19 \\
\cdot 16 \\
\cdot 19 \\
.21 \\
.24 \\
\cdot 16 \\
.24 \\
\cdot 16\end{array}$ & $\begin{array}{r}56 \cdot 17 \\
\cdot 17 \\
\cdot 20 \\
\cdot 12 \\
\cdot 14 \\
.09 \\
\cdot 14 \\
\cdot 09 \\
.09 \\
\cdot 14 \\
\cdot 12 \\
\cdot 20 \\
\cdot 14 \\
\cdot 12\end{array}$ & $\begin{array}{r}56 \cdot 10 \\
.20 \\
.15 \\
.12 \\
.00 \\
.15 \\
.12 \\
.10 \\
.10 \\
.18 \\
.05 \\
.15 \\
15 \\
.02\end{array}$ \\
\hline $\begin{array}{l}\text { Mean ................ } \\
\text { Probable error ... } \\
\text { Thermometer } \ldots\end{array}$ & $\left|\begin{array}{c}56 \cdot 19 \\
004 \\
2\end{array}\right|$ & $\mid \begin{array}{c}56 \cdot 18 \\
006 \\
2\end{array}$ & $\begin{array}{c}56 \cdot 18 \\
\cdot 007 \\
2\end{array}$ & $\begin{array}{c}56 \cdot 18 \\
006 \\
2\end{array}$ & $\begin{array}{c}56 \cdot 16 \\
\cdot 009 \\
2\end{array}$ & $\left|\begin{array}{c}56 \cdot 19 \\
.007 \\
2\end{array}\right|$ & $\begin{array}{c}56 \cdot 14 \\
\cdot 006 \\
2\end{array}$ & $\begin{array}{c}56 \cdot 11 \\
\cdot 010 \\
3\end{array}$ \\
\hline
\end{tabular}


Table XXV.

Summary of Results.

\begin{tabular}{|c|c|c|c|c|}
\hline Substince. & $\begin{array}{l}\text { Woighted } \\
\text { mean. }\end{array}$ & $\begin{array}{l}\text { Probable } \\
\text { error. }\end{array}$ & $\begin{array}{c}\text { After } \\
\text { Poggendorff's } \\
\text { correction. }\end{array}$ & $\begin{array}{c}\text { Air- } \\
\text { thermometer. }\end{array}$ \\
\hline Toluidine ...... & $42 \cdot 765$ & $\cdot 004$ & $42 \cdot 700$ & $42 \cdot 890$ \\
\hline Nitrophenol $(\alpha)$.. & $44 \cdot 270$ & $\cdot 003$ & $44 \cdot 205$ & $44 \cdot 392$ \\
\hline Nitrotoluol ..... & $51 \cdot 305$ & .005 & $51 \cdot 239$ & $51 \cdot 407$ \\
\hline Dichlorobenzol . & 52723 & .002 & $52 \cdot 657$ & $52 \cdot 821$ \\
\hline Nitronaphthalin . & $56 \cdot 175$ & 002 & $56 \cdot 110$ & $56 \cdot 261$ \\
\hline Dinitrophenol $(a)$. & $61 \cdot 778$ & $\cdot 003$ & $61 \cdot 714$ & $61 \cdot 843$ \\
\hline Monobromaniline . & $61 \cdot 806$ & .003 & $61 \cdot 742$ & $61 \cdot 871$ \\
\hline Dinitrotoluol $(a) \ldots$. & $69 \cdot 211$ & .004 & $69 \cdot 154$ & $69 \cdot 252$ \\
\hline ",$\quad$ (b) .... & $69 \cdot 571$ & $\cdot 00 t$ & $69 \cdot 514$ & 69610 \\
\hline Monochloraniline ...... & $69 \cdot 667$ & .003 & $69 \cdot 610$ & $69 \cdot 706$ \\
\hline Dinitrobromobenzol... & $70 \cdot 598$ & $\cdot 00 t$ & $70 \cdot 542$ & $70 \cdot 634$ \\
\hline Trichloraniline ......... & $77 \cdot 052$ & .001 & $77 \cdot 004$ & 77.068 \\
\hline Dibromaniline ......... & $78 \cdot 821$ & .004 & $78 \cdot 776$ & $78 \cdot 833$ \\
\hline Trinitrotoluol ... & $78 \cdot 841$ & .004 & 78796 & $78 \cdot 853$ \\
\hline Naphthalin .......... & $80 \cdot 061$ & .002 & 80018 & $80 \cdot 070$ \\
\hline Trinitrotoluol (M) $\ldots$ & $80 \cdot 524$ & $\cdot 003$ & $80 \cdot 481$ & $80 \cdot 532$ \\
\hline Nitrodibromobenzol ... & $83 \cdot 490$ & .002 & $83 \cdot 452$ & 83.492 \\
\hline Dibromobenzol .......... & $87 \cdot 037$ & .002 & 87.007 & 87.035 \\
\hline Dinitrobenzol .......... & $89 \cdot 718$ & $\cdot 003$ & $89 \cdot 693$ & $89 \cdot 712$ \\
\hline Nitrophenol ............. & $111 \cdot 413$ & $\cdot 006$ & $111 \cdot 448$ & $111 \cdot 455$ \\
\hline Dinitrophenol .......... & 111.579 & .001 & $111 \cdot 614$ & $111 \cdot 621$ \\
\hline Tribromaniline ......... & $116 \cdot 247$ & $.00 \overline{3}$ & $116 \cdot 298$ & $116 \cdot 319$ \\
\hline Trinitrophenol ... & $121 \cdot 092$ & .005 & $121 \cdot 151$ & $121 \cdot 194$ \\
\hline
\end{tabular}

\section{Discussion.}

The determinations of melting-point which have been recorded in the preceding tables, and the results of which are summarized in Table $\overline{X X V}$, show a very small probable error in connexion with their weighted means. The probable error of a weighted mean has ranged from $0^{\circ} 001$ to $0^{\circ} \cdot 006$, its average value being less than $0^{\circ} .004$. So far, then, as regards the actual process of ascertaining melting-point, considerable accuracy has doubtless been attained.

The preliminary operation of calibrating the thermometers was so conducted as not to have introduced material error, as indeed is obvious from a comparison of the results obtained with different thermometers on melting the same substance*. Regnault was of opinion that the height of the barometer cannot be ascertained with a less error than about 0.1 millim. Such an error would correspond to about $0^{\circ} .0037$ on $100^{\circ}$; and the error would be still less on the mean, as in the present case, of several readings. The small errors in the determination of the exposure-corrections could not sensibly affect the * See, for instance, Table VII. 
final results. It is to comparison with the air-thermometer that we have to look for any important source of error. All observers who have made an extended range of such comparisons have found noteworthy errors, though they have in no case stated probable error. The probable error of the result of my own comparisons of thermometer 2 with the air-thermometer is $0^{\circ} 085$ for a single set of comparisons, or $0^{\circ} .085$ $\div \sqrt{33}=0^{\circ} 015$ for the results of the thirty-three sets. This number is the measure of probable error of the equation employed in the final reductions. Compounding, then, the mean probable error of the melting-point $(\cdot 004)$ with that of the comparison (.015) with the air-thermometer, we may consider the melting-points in Table XXV. ascertained, in terms of the air-thermometer, with a probable error of

$$
\sqrt{(\cdot 004)^{2}+(\cdot 015)^{2}}=0 \cdot 015 \text {. }
$$

The relation of the chemical symbol to the physical properties of a substance is a matter of such great interest that $I$ have sought for it in melting-point, although other investigators of the general subject, working with less definite data, have not arrived at very encouraging results.

It is very easy to show that, in some cases, there is a very simple connexion between the formula and the melting-point of a substance in the centigrade scale. Thus, dichlorobenzol, bromaniline, and trinitrotoluol form a grovp in which meltingpoint $=\phi \times$ numerical value of formula.

Substance. Formula.

Dichlorobenzol . $\mathrm{C}_{6} \mathrm{H}_{4} \mathrm{Cl}_{2}=147$

Bromaniline . . $\mathrm{C}_{6} \mathrm{H}_{6} \mathrm{BrN}=172$

Trinitrotoluol $. \mathrm{C}_{7} \mathrm{H}_{5} \mathrm{~N}_{3} \mathrm{O}_{6}=227$

In the first of these two instances the values of $\phi$ are almost exactly the same; in the last, however, the limits of probable error are exceeded, though a close approximation is very evident.

The following comparison furnishes another practical identity:-

$$
\text { Melting-point. }
$$

Melting-point.

$\left.\begin{array}{l}\text { Trinitrotoluol . } 78 \cdot 853 \text { - Dinitrotoluol . } 69.252=9 \cdot 601 \\ \text { Trinitrophenol. } 121 \cdot 194 \text { - Dinitrophenol. } 111 \cdot 621=9 \cdot 573\end{array}\right\}$

In the next instance there is an approximation:-

Melting-point.

Melting-point.

Dinitrotolual . $69 \cdot 252$ - Nitrotolnol . $5 \AA \cdot 407=17 \cdot 845$ )

Dinitrophenol. $61 \cdot 843$ - Nitrophenol. $44 \cdot 392=17 \cdot 451\}$ 
Such illustrations may be of service in enabling us to detect, with more or less probability, the parallelism of chemical series, and to enable us to decide whether a function-nitration, for example-has or has not the same value in different parts of a series. Other groups in which a similar but less intimate relation prevails, might be adduced from the list; and a glance at Table XXV. will show that, on the whole, melting-point and formula grow together. It may not improbably prove to be the case that, when the whole subject of melting-point has been successfully investigated, this simple, relation is the limiting condition of the real law. The data, however, hitherto adduced are far from adequate to a discussion of numerical relations among melting-points: for such an object it would be a fruitless task to examine them further.

Some negative results of this investigation are worthy of attention. Thus $\alpha$ and $\beta$ nitrophenol have the same additive formula, and yet differ by $67^{\circ} .063$ in their melting-point. It is clear then, as already well known, that melting-point may, in casos of isomerism, be related to something else than formula. The melting-point of naphthalin is actually lowered in the first stage of nitration. Considerations such as these may perhaps serve as suggestions for future work.

An accurate method of determining melting-point places it within our power to detect far more delicate shades of isomeric differences than have hitherto been regarded as possible. Thus strong presumptive evidence has been adduced (p. 14) that dinitrotoluol, when prepared directly from toluol or from liquid (meta-) nitrotolnol, or from solid (para-) nitrotoluol by gentle nitration, melts at $69^{\circ} \cdot 252$; but that when paranitrotoluol is energeticaly nitrated, the product melts at $69^{\circ} \cdot 610$. There are consequently two modifications of dinitrotoluol obtainable very directly from toluol-the melting-point of these substances differing by $0^{\circ} .358$, a quantity far beyond the range of error of the method. In like manner, it can be shown that two parallel modifications of trinitrotoluol existone of which melts at $78^{\circ} .853$, the other at $80^{\circ} .532^{*}$.

[For a complete account of the thermometers referred to in this memoir the reader is referred to the Transactions of the Royal Society of Edinburgh, 1881, p. 567; for the method of determining melting-point, to the Proceedings of the Royal Society, vol. xxxiii. p. 203.]

* Compare Phil. Mag. 1875, 1. p. 17. 